\title{
Replication Factor C from the Hyperthermophilic Archaeon Pyrococcus abyssi Does Not Need ATP Hydrolysis for Clamp-loading and Contains a Functionally Conserved RFC PCNA-binding Domain
}

\author{
Ghislaine Henneke ${ }^{1,2}$, Yannick Gueguen ${ }^{1}$, Didier Flament ${ }^{1}$, Philippe Azam ${ }^{1}$, Joël Querellou ${ }^{1}$, \\ Jacques Dietrich $^{1}$, Ulrich Hübscher ${ }^{2}$ and Jean-Paul Raffin ${ }^{1_{*}}$
}

\footnotetext{
${ }^{1}$ Ifremer, Laboratoire de Microbiologie et Biotechnologie des Extrêmophiles, DRV/VP, BP 70, F-29280, Plouzané, France

${ }^{2}$ Institute of Veterinary Biochemistry and Molecular Biology, University of Zürich, Winterthurerstrasse $190, \mathrm{CH}-$ 8057, Zurich, Switzerland
}

*ipraffin@ifremer.fr

\begin{abstract}
The molecular organization of the replication complex in archaea is similar to that in eukaryotes. Only two proteins homologous to subunits of eukaryotic replication factor C (RFC) have been detected in Pyrococcus abyssi (Pab). The genes encoding these two proteins are arranged in tandem. We cloned these two genes and co-expressed the corresponding recombinant proteins in Escherichia coli. Two inteins present in the gene encoding the small subunit (PabRFC-small) were removed during cloning. The recombinant protein complex was purified by anion-exchange and hydroxyapatite chromatography. Also, the PabRFC-small subunit could be purified, while the large subunit (PabRFC-large) alone was completely insoluble. The highly purified PabRFC complex possessed an ATPase activity, which was not enhanced by DNA. The Pab proliferating cell nuclear antigen (PCNA) activated the PabRFC complex in a DNA-dependent manner, but the PabRFC-small ATPase activity was neither DNA-dependent nor PCNA-dependent. The PabRFC complex was able to stimulate PabPCNA-dependent DNA synthesis by the Pabfamily $D$ heterodimeric DNA polymerase. Finally, (i) the PabRFC-large fraction cross-reacted with anti-human-RFC PCNA-binding domain antibody, corroborating the conservation of the protein sequence, (ii) the human PCNA stimulated the PabRFC complex ATPase activity in a DNA-dependent way and (iii) the PabRFC complex could load human PCNA onto primed single-stranded circular DNA, suggesting that the PCNA-binding domain of RFC has been functionally conserved during evolution. In addition, ATP hydrolysis was not required either for DNA polymerase stimulation or PCNA-loading in vitro.
\end{abstract}

Keywords: replication factor C; archaea; hyperthermophile; Pyrococcus abyssi; PCNA-binding domain 


\section{Introduction}

Chromosome DNA replication occurs in a strikingly similar manner in diverse organisms, requiring for a DNA replication complex, a DNA polymerase holoenzyme that is functionally conserved between eucarya, bacteria and the bacteriophage T4 ${ }^{1}$. The holoenzyme is composed of three essential protein components: (i) a DNA polymerase, (ii) a processivity factor (the sliding-clamp), (iii) a multi-protein complex (the clamploader). DNA polymerases alone lack high processivity but upon association with their respective sliding-clamps, they can duplicate long chromosome continuously and accurately. The only known physiological mechanism by which the sliding-clamp can be assembled onto DNA is through its ATP-dependent interaction with the clamp-loader. The clamp-loading process has been studied in all systems ${ }^{2-10}$.

In eukaryotes, the RFC clamp-loader is formed by five subunits ${ }^{11}$. The RFC clamploader loads the homotrimeric PCNA clamp onto DNA in an ATP-dependent manner ${ }^{12}$. While PCNA associates with DNA polymerase $\delta^{13}$ or $\varepsilon^{14}$, processive DNA synthesis occurs ${ }^{15}$ and RFC is thought to dissociate from DNA ${ }^{16}$. In all systems tested, the kinetic mechanisms of holoenzyme assembly require many intermediate structural intermediate complexes and ATP hydrolysis ${ }^{3,4,17}$. The exact nature of the ATP hydrolysis events and the conformational changes required for loading the ring-shaped sliding-clamp onto DNA in these organisms have recently been described in details ${ }^{6-9}$.

The cellular structure and metabolism of archaea, the third domain of life ${ }^{18}$, are similar to bacteria. However, archaeal DNA replication systems are homologous to those of eukaryotes. The complete archaeal genome sequencing ${ }^{19-24}$ has allowed identification of putative homologues of eukaryotic DNA replication proteins. Interestingly, DNA 
replication mechanisms seem to be quite different within the archaeal subdomains. Whereas the crenarchaeotes, a subdomain of archaea, contain two ${ }^{25}$ or three ${ }^{23}$ PCNA homologues, and two or three family B DNA polymerases ${ }^{26,27}$, the euryarchaeotes possess only one PCNA homologue ${ }^{28,29}$, one family B and one family D DNA polymerase respectively ${ }^{30-32}$. The evolution of PCNA homologues has been characterized by one or two gene duplication events, which are believed to have occurred after the split of the crenarchaeal and euryarchaeal lineages ${ }^{33}$. In archaea, two genes with homology to RFC have been identified. They share sequence homology with their eukaryotic counterparts. Seven amino acid motifs (referred to as boxes II to VIII) in both RFC subunits are highly conserved. However, so far experimental evidence is lacking that shows the involvement of the archaeal proteins in DNA replication or that they play other cellular roles, such as in DNA repair.

Recent structural and biochemical studies of archaeal clamp-loaders have revealed surprising discrepancies. While the Sulfolobus solfataricus and Pyrococcus furiosus clamp-loaders form apparently a heteropentamer ${ }^{34,35}$, the RFC complex from the euryarchaeote Methanobacterium thermoautotrophicum appears to be a hexamer ${ }^{36}$. Pyrococcus abyssi $(\mathrm{Pab})$ is an anaerobic hyperthermophilic euryarchaeon with an optimal growth temperature at $96^{\circ} \mathrm{C}{ }^{37}$. The entire genome sequence of Pyrococcus abyssi was recently published (http://www.genoscope.cns.fr/Pab/). Amino acid sequence comparisons with eukaryotic homologous proteins showed that DNA replication components (DNA polymerases, PCNA, RFC and RPA) are also conserved. Three open reading frames (ORFs) encoding putative homologues of eukaryotic RFC subunits and PCNA have been identified. Here, we describe the isolation and characterization, of a 
RFC complex homologue from Pyrococcus abyssi (PabRFC). This complex is a fully active clamp-loader, able to load PCNA onto a DNA heteroduplex and to stimulate the PCNA-dependent primer-extension abilities of PabDNA pol II. Our data also suggest that the PCNA-binding domain of the RFC is functionally conserved from archaea to human. 


\section{Results}

\section{Identification of the clamp-loader complex and genetic organization of Pyrococcus}

abyssi. A BLASTX analysis of the genomic database of Pyrococcus abyssi identified two putative genes homologous to the large and small eukaryotic RFC subunits: PabRFCsmall and PabRFC-large. These two genes are arranged in tandem on the P. abyssi chromosome. They form a 5765 bp operon (Figure 1) and are separated by a short intergenic sequence (11 bp). Analysis of the location of the PabRFC cluster genes showed that they are located within an archaeal origin of replication spot ${ }^{38}$ containing genes homologous to the eukaryotic counterparts involved in the initiation (such as Cdc6/Orc1) and elongation of DNA replication (the two subunits of the new archaealtype family D DNA polymerase ${ }^{32}$ ). In addition, this region is composed by genes encoding for a putative DNA helicase and for a Rad51 homologue (Figure 1, top).

PabRFC-small and PabRFC-large are 4314 bp and 1440 bp long, respectively. The PabRFC-small gene is only 993 bp long after the excision of the two inteins. Putative transcriptional and translational signals have also been identified (Figure 1, bottom).

The amino acid sequences of the PabRFC subunits were compared together with those of archaeal, eukaryotic and prokaryotic homologues (Figure 2). Similarities were found in seven regions known as RFC boxes II-VIII (Figure 2A). When the inteins were excised, PabRFC-small was found to be $37 \%$ identical to the human RFC p40 subunit. PabRFC-large showed the conserved RFC boxes observed in the large human RFC p140 subunit, but not all of the motifs are present in the PabRFC-large subunit. An additional box (I), showing homology to prokaryotic DNA ligases and poly(ADP-ribose) polymerases ${ }^{39}$, is a BRCT module and is part of the $\mathrm{N}$-terminal region of the human RFC 
140, but not in the PabRFC-large subunit (Figure 2A). The identifiable boxes ${ }^{40}$ shared by the five RFC polypeptides contain three well defined motifs: two of these boxes contain putative ATP-binding sequences (boxes III and V) known as Walker A (P-loop) and B motifs ("DEAD box"), respectively (Figure 2B). Also, the conserved p21-like PCNA-binding motif $(\mathrm{QXX}(\mathrm{h}) \mathrm{XX}(\mathrm{a})(\mathrm{a}))^{41}$ is present at the C-terminal part of the PabRFC-large subunit.

\section{Expression and subunits composition of the PabRFC-complex. PabRF-small}

and PabRFC-large genes were cloned separately into a pET expression vector. The small subunit was expressed as a soluble product, but unfortunately the large subunit remained insoluble (data not shown). To overcome this problem, we decided to coexpress both subunits into E. coli. The expressed PabRFC-complex soluble and N-terminal sequencing confirmed the identity of the subunits; the partial $\mathrm{NH}_{2}$-terminal sequences were, as expected: V-R-D-M-E-E-V-R-E-V, for PabRFC-small; and P-E-V-P-W-V-E-K-Y-R-P, for PabRFC-large. Heat treatments and alternative different protocols were used to purify the complex to apparent homogeneity (Figure 3, and see also "Materials and Methods"). The protocol yielded high amounts of recombinant proteins since typically about $5 \mathrm{mg}$ of purified PabRFC-complex were obtained from a 1.5 liters of an E. coli culture. To try to determine the subunit composition of the recombinant PabRFC-complex, different amount of purified PabRFC-complex were separated on 10\% SDS-PAGE and stained with coomassie blue. The gels were scanned and the relative concentrations of each subunit present in the purified $P a b$ RFC fraction were quantified. $P a b$ RFC-complex yielded distinct mass ratios from 2:1 to 4:1, for PabRFC-small and PabRFC-large, 
respectively, depending on the preparation and the purification procedures. Analytical gel filtration gave two peaks (Figure 4). The identity of the two RFC subunits was visualized by SDS-PAGE and silver staining. The two peaks eluted at 250 and $134 \mathrm{kDa}$ respectively, corresponding to a putative heterohexamer (4 RFC-small : 2 RFC-large) and a heterotrimer (2 RFC-small : 1 RFC-large) complex.

\section{The anti-hRFC p140 PCNA-binding domain antibody cross-reacts with}

PabRFC-large. The PabRFC-large fraction was subjected to western blot analysis with either the mouse monoclonal anti-DNA-binding domain or the rabbit polyclonal antiPCNA-binding domain antibodies generated from human RFC p140. The anti-PCNAbinding domain polyclonal antibody cross-reacted with PabRFC-large (Figure 5). This further confirms the conclusions inferred from the protein sequence analysis, suggesting that both eukaryotic and archaeal large subunits share a common PCNA-binding motif (see also below). In contrast, the absence of a structurally conserved DNA-binding domain within the PabRFC-large, as expected by amino acids alignments, was confirmed by Western blotting (Figure 5).

Characterization of the PabRFC-complex ATPase activity. The recombinant PabRFC-complex possesses a strong intrinsic ATPase activity. Unexpectedly, this activity was not stimulated by the presence of DNA (Figure 6A). Primed single-stranded circular templates or single-stranded linear templates, and double-stranded linear templates did not stimulate the ATPase activity of PabRFC (results not shown). We initially hypothesized that DNA stimulation could be masked by the strong intrinsic 
PabRFC ATPase activity. Therefore, a low concentration of RFC (50 ng) was used for DNA titration. Again, DNA had no effect on ATPase activity, even at non-physiological concentrations (up to $150 \mu \mathrm{M}$; results not shown). Furthermore, polymin-P treatment and quantitation of DNA were done to exclude unspecific DNA-stimulation on the PabRC ATPase activity, due to the presence of genomic DNA into our preparation. Finally, we also excluded the possibility that DNA was denatured in the reaction mixtures. All experiments were performed at a temperature that was $5-10^{\circ} \mathrm{C}$ lower than the melting temperature of the heteroduplex, preventing the destructuration of the double-stranded DNA. Finally, the ATPase activity of the PabRFC-small subunit was DNA-independent (Figure 6B). The PabRFC complex hydrolyzed also dATP at a rate about two times lower than ATP (results not shown).

Next, the effect of recombinant PabPCNA on the rate of ATP hydrolysis was examined in the presence of a circular DNA heteroduplex. PabPCNA stimulated the intrinsic ATPase activity of PabRFC-complex (Figure 6C); $50 \mathrm{ng}$ PabPCNA led to a 2fold increase of the ATPase activity, either with 50 or $250 \mathrm{ng}$ of PabRFC-complex. Interestingly, this effect was strictly DNA-dependent. Conversely, PabPCNA did not stimulate the ATPase activity of the PabRFC-small subunit, in the presence or absence of the DNA heteroduplex (Figure 6D).

As shown in Figs. 2A and 5, the PCNA-binding domain of the PabRFC-large subunit shares conserved binding motifs in archaea and human. We investigated the effect of the human PCNA on the PabRFC-complex ATPase activity. Since the hPCNA is not active above $50^{\circ} \mathrm{C}$, and the PabRF ATPase activity can not easily be detected at $37^{\circ} \mathrm{C}$, we used $45^{\circ} \mathrm{C}$ as the incubation temperature. In this heterologous system, higher 
protein concentrations were required to detect the effect, but the stimulation of the PabRFC ATPase activity by the hPCNA was evident and was also strictly dependent on the presence of a DNA heteroduplex (Figure 7A). The maximal effect was obtained with $500 \mathrm{ng}$ of hPCNA and with $500 \mathrm{ng}$ of PabRFC-complex (Figure 7B).

PabRFC is required for efficient DNA synthesis by PabPol II. When PabPCNA and PabRFC were absent, no full-length M13 product was detected (Figure 8, lanes 1 and 2). A major product was obtained near $1.5 \mathrm{~kb}$, probably because of the presence of secondary structures within the circular M13 single-stranded DNA. PabRFC-complex stimulated the PabPCNA-dependent DNA synthesis by PabPol II, increasing the amount of full length M13 products (Figure 8, lanes 7 and 8). PabPCNA alone stimulated PabPol II (Figure 8, lane 3), but to a much lesser extent than when PabRFC-complex was added (Figure 8, lane 8). ATP was not required to obtain full stimulation (compare lanes 7 and 8 of Figure 8). In fact, ATP seemed lowered the effects of the PabPCNA (compare lanes 3 and 5 of Figure 8).

\section{PabRFC can load hPCNA on primed single-stranded circular DNA in the} presence of non-hydrolyzable ATP. As the PCNA-binding domain is conserved in the PabRFC, and that hPCNA could stimulate PabRF ATPase activity in a DNA-dependent manner, we used the well characterized phosphorylable ph-PCNA derivative to measure the clamp-loading activity of the PabRFC-complex, using the cross-linked PCNA-DNA

complex technique ${ }^{42}$. When ATP was added to the incubation mixture, no loading could be detected (Figure 9, lane 2). However, weak loading was detected in the absence of 
ATP (Figure 9, lane 4). This loading was not detected when double-stranded DNA was used, showing that it is specific (Figure 9, lane 3). As ATP can also stimulate the unloading activity of RFC, we next measured the effect of ATP- $\gamma-\mathrm{S}$, a non-hydrolyzable ATP analogue, which only stimulates the loading activity of $\mathrm{RFC}^{43}$. An extensive loading was detected with this ATP analogue (Figure 9, lane 5), suggesting that ATP hydrolysis is not a prerequisite for loading but is likely involved into the clamp-unloading mechanism. 


\section{Discussion}

In this paper we describe the isolation in high amounts and the biochemical characterization of the recombinant non-tagged dimeric RFC-complex of the euryarchaeote $P$. abyssi. The two subunits are arranged in tandem within a $80 \mathrm{~kb}$ region that contains the origin of replication ${ }^{38}$. Other proteins involved in the initiation and elongation of DNA replication are also present in this region (e.g. Cdc6, Pol II and Rad51). In bacteria, clusters of replication genes near the origin of replication trigger the effective assembly of replication forks at the origin ${ }^{44}$. The flanking region upstream of the RFC genes cluster contains a hexanucleotide AT-rich sequence (TATAAT) similar to the archaeal TATA box ${ }^{45}$. This sequence is located 15 nucleotides upstream of a TGGT motif. These putative promoter elements are equivalent to the eukaryotic regulation transcription boxes $\mathrm{A}$ and $\mathrm{B}$, respectively ${ }^{46}$. Moreover, neither putative termination sequences nor putative transcription initiation boxes have been identified immediately downstream of the PabRFC-small gene. This suggests that this gene cluster, organized as an operon, is co-transcribed like a polycistronic mRNA. This in turn probably reflects the functionality of a typical thymidine-rich archaeal termination sequence downstream of the PabRFC-large gene (Figure 1) ${ }^{47}$. Two putative translation signals have been identified upstream of the RFC genes. These regions are homologous to Shine Dalgarno regulatory sequences ${ }^{47}$ and they most likely function as ribosome-binding sites.

The two RFC homologues share sequence homologies with their eukaryotic counterparts. The Walker A motif is assumed to form a phosphate-binding loop that interacts with the triphosphate tail of ATP, whereas the Walker B motif interacts with the $\mathrm{Mg}^{2+}$ required for ATP hydrolysis ${ }^{48}$. The C-terminal part of both PabRFC subunits is 
unique, indicating that they have a specific and distinct role in the RFC complex as in the case for the eukaryotic counterparts ${ }^{49}$. The N-terminal part of the PabRFC-large subunit lacks the motif that shows homologies with prokaryotic DNA ligases and poly(ADPribose) polymerases (the BRCT module) ${ }^{39}$. The function of this RFC A box is still unknown since RFC substitution in human and yeast cells by a RFC lacking the ligase homology domain showed no phenotype linked to DNA replication, DNA damage, telomere length maintenance or intrachromosomal recombination ${ }^{50,51}$.

The primary translation products of several archaeal proteins involved in DNA replication contain inteins that are rapidly excised in vivo ${ }^{52}$. Some RFC small subunits from archaea contain inteins. Methanocaldococcus jannaschii RFC small subunit contains three inteins (prototype alleles: Mja RFC1, Mja RFC2 and Mja RFC3) at the RFC-a, RFC-b and RFC-c insertion sites. In Pyrococcus abyssi, only sites a and c contain inteins while other Pyroccosus species contain only intein Mja RFC1. In Methanopyrus kandleri, only the Mja RFC2 allele is found. Most archaeal RFC-small subunits (including Methanobacterium thermoautotrophicum and Sulfolobus solfataricus) do not contain inteins. Also, no biochemical characterization of the RFC inteins has been reported so far. Insertion of inteins occurs at specific and conserved motifs such as the phosphate-binding loop (P-loop) involved in the binding of phosphate nucleotide groups ${ }^{53}$. Despite these observations, our current understanding of such splicing proteins, specifically in DNA replication proteins, is very limited. The excision of the inteins is a prerequisite for protein function.

Well-studied clamp-loaders include the gp44/62 complex from bacteriophage T4, RFC from eukaryotes (human and yeast RFC) and the $\gamma$-complex from E. coli ${ }^{2}$. All of 
these clamp-loaders consist of five-subunits. Recently, three archaeal RFC homologues were characterized: MthRFC from Methanobacterium thermoautotrophicum ${ }^{36}$, SsoRFC from Sulfolobus solfataricus ${ }^{34}$, and PfuRFC from Pyrococcus furiosus ${ }^{35}$. As described for $M t h \mathrm{RFC}^{36}$, the stability of the PabRFC complex is dependent on high salt concentration. Indeed, dialysis against a low ionic strength buffer led to the dissociation of the complex, releasing PabRFC-small and PabRFC-large. PabRFC-large then formed an insoluble aggregate. Also, E. coli-expressed PabRFC-large was completely insoluble. Different results were reported on the respective subunit composition. The large and small subunits of the $M$. thermoautotrophicum clamp-loader assemble in a hexameric structure, containing two large and four small subunits. The recombinant $S$. solfataricus RFC described to be ATP-dependent, is organized into a heteropentamer with one large and four small subunits ${ }^{34}$. The PfuRFC complex consisted of three or four small subunits and one or two large subunits ${ }^{35}$, but further biochemical and structural analyses are apparently necessary to characterize the active form of the PfuRFC complex. Indeed, the gel filtration and glycerol gradient centrifugation protocols, which have been described to determine the oligomeric structure of archaeal RFC complexes, can definitively not distinguish between a pentamer and a hexamer. In this study, gel filtration chromatography yielded two species, probably as a result of a partial dissociation of the PabRFC-complex on the column at the low salt concentration used. Sedimentation equilibrium would be the most appropriate technique if a precision better than $10 \%$ could be achieved and if the structure of the RFC complex would be symmetrical. Recently, the atomic structure of the clamp-loader small subunit from Pyrococcus furiosus was reported ${ }^{54}$. This complex assembled as a double trimer. This organization may reflect an 
alternative conformation adopted by the clamp-loader when only a subset of subunits is present in the complex ${ }^{55}$, but could indicate that the structure of the RFC complex would also be asymmetrical. Therefore, the resolution of the oligomeric structure of the archaeal RFC complex awaits crystallographic data. This question takes a particular importance as substantial differences in clamp-loading mechanisms could be associated with different RFC subunits complexes. Because of subunits contain a consensus ATP-binding domain, the relative numbers of ATP molecules localized either in unique or identical subunits could differ ${ }^{56}$. This is important, given that multiple stepwise ATP-binding events are required to load PCNA onto primed DNA ${ }^{7}$, and that the ATP-binding domains of the small RFC subunits are essential for DNA recognition and clamp-loading ${ }^{8}$. In addition, the eukaryotic small subunits core complex may have different specific functions upon association with different types of large subunits ${ }^{57,58}$.

The ATPase activity of the archaeal RFC differs from that of the eukaryotic RFCs (Table 1) and there are also remarkable differences between the four archaeal RFC complexes. The ATPase activity of PabRFC is strongly DNA-independent. Similar results were obtained with RFC fraction A and the polymin P-treated RFC fraction B, which excluded any DNA into the preparation of the PabRFC. The PabRFC-small subunit had similar ATPase activity compared to the RFC-complex. Moreover, ATPase activity assays were performed in the presence of varying amounts of poly $(\mathrm{dA}) / \mathrm{oligo}(\mathrm{dT})$, primed M13ssc or primed $\lambda$ DNA, and no stimulation was observed with all DNA concentrations tested (data not shown). The effect of PCNA was strictly DNA-dependent. The ATPase activity of the Pyrococcus furiosus RFC-complex was only moderately activated by DNA ${ }^{35}$, which would suggest that a low sensitivity of the RFC 
to DNA is a general feature within the Thermococcales group. The effect of PCNA on the MthRFC ATPase activity was strictly dependent on the presence of $\mathrm{SSB}^{36}$. This may also be the case for the SsoPCNA, as the measurements were made in the absence of $\mathrm{SSB}^{34}$. The PabRFC-complex behaves like a DNA-dependent PCNA-activated ATPase. This high DNA-dependency of the effect of PCNA would also indicate that the PabRFCcomplex preparation is not contaminated by DNA.

The RFC homologue from Pyrococcus furiosus is not strictly dependent on ATP for its clamp-loading activity ${ }^{35}$. It has been suggested that the PfuRFC possesses the ability to unload the PCNA from the DNA heteroduplex and also that dATP could substitute for ATP in the loading reaction. However, earlier studies looked for dATPase activity or DNA polymerase stimulation. In this study, we measured the loading which could take place in the absence of any hydrolyzable ATP analogue. Therefore, we suggest that ATP hydrolysis is not a prerequisite for loading but might enhance the clamp-unloading activity of the PabRFC-complex. These observations, and the fact that archaeal PCNA can stimulate DNA polymerase on primed circular DNA, in the absence of RFC, are still puzzling. An explanation could be that PCNA can perform subunit exchange at elevated temperatures $\left(60-65^{\circ} \mathrm{C}\right)$ and thus could be loaded onto circular DNA, in the absence of RFC. This model already suggested for different archaeal DNA replication systems points out a new potential role of archaeal RFC. Our findings strongly support this idea: (i) PCNA can be loaded spontaneously without the clamp-loader; (ii) ATP hydrolysis is not a prerequisite for loading; (iii) the spontaneous loaded PCNA, together with DNA, clearly stimulates the ATPase activity of the RFC. Then, the question arises: what is the enzymatic step that requires ATP hydrolysis? We propose that a new functional role of 
RFC could be attributed to its clamp-unloading activity. Other arguments favor this hypothesis. PCNA stimulation onto the processivity of DNA pol II was optimal either with or without RFC, whereas in presence of both replication factors (RFC, PCNA) and ATP, the distributivity of the polymerase was stimulated (increasing amounts of intermediates). Thus, the altered polymerase activity might be due to the clamp-unloading RFC dynamic process.

We showed that the PCNA-binding domain is structurally and functionally conserved from archaea to human. The fact that the archaeal PCNA can stimulate the activity of DNA polymerase $\delta^{29}$, and that human RFC interacts functionally with the archaeal PCNA ${ }^{59}$, emphasizes that the structure of the PCNA is conserved. We have demonstrated that the archaeal RFC, not only interacts functionally with the hPCNA, but can also load the sliding clamp onto singly primed, single-stranded circular DNA. The PCNA-binding domain is conserved among all the RFC subunits. However, the PCNAbinding domain of the human RFC p140 was sufficient to load the PCNA onto DNA ${ }^{50}$. On the other hand, the RFC small subunit complex of Pyrococcus furiosus was able to stimulate the PCNA-dependent primer-extension abilities of the cognate DNA polymerase ${ }^{60}$. Therefore, there could exist more than one site of interactions between the clamp-loader and the clamp. A conserved PCNA-binding motif found in a variety of proteins interacting with PCNA ${ }^{41}$ was reported at the C-terminus of the Archaeoglobus fulgidus RFC large subunit ${ }^{61}$. Interestingly, this motif is present in all euryarchaeota (protein sequences available for 11 species), but is lacking in crenarchaeota with the exception of Aeropyrum pernix (4 protein sequences available). The eukaryotic RFC could have evolved from a hypothetical ancestral homohexameric clamp-loader and the 
archaeal RFC would represent an intermediate stage of this evolution. Therefore, one can expect that studies on the DNA replication machinery of archaea will provide important clues for understanding the complex mechanisms of DNA replication in eukaryotes.

Footnote: Jean-Paul Raffin is a researcher at the Centre National de la Recherche Scientifique (CNRS).

Abbreviations used:

Pab, Pyrococcus abyssi; PabDNA pol I, Pyrococcus abyssi family B DNA polymerase; PabDNA pol II, Pyrococcus abyssi family D DNA polymerase; PabPCNA, Pyrococcus abyssi Proliferating Cell Nuclear Antigen; hPCNA, human Proliferating Cell Nuclear Antigen; ph-PCNA, phosphorylable derivative of the human Proliferating Cell Nuclear Antigen; PabRFC-complex, Pyrococcus abyssi Replication Factor C; PabRFC-small, Pyrococcus abyssi Replication Factor C small subunit; PabRFC-large, Pyrococcus abyssi Replication Factor C large subunit; RPA, Replication Protein A; SSB, single-stranded DNA-binding protein; MCM, Minichromosome Maintenance Protein; M13ssc, singlestranded circular M13mp18 DNA; M13ds, double-stranded M13mp18 DNA; ATP- $\gamma-S$, adenosine 5'-O-(3-thiotriphosphate); IPTG, isopropyl-1-thio- $\beta$-D -galactopyranoside; PVDF, polyvinylidene difluoride membrane; DTT, Dithiothreitol; LB, Luria-Bertani broth; nt, nucleotide; bp, base pair. 
Acknowledgements: G. Henneke and U. Hübscher are supported by the Swiss National Science Foundation (grant 31.61361.00) and by the Kanton of Zürich. We thank Dr. B. Stillman for providing purified mouse monoclonal anti-human RFC DNA-binding domain region antibody, and Prof. J.M. Masson for providing the E. coli strain MC1061(DE3). We acknowledge Prof. Joel Janin for very helpful discussion on the oligomeric structure of the RFC-complex. 


\section{Materials and Methods}

\section{Materials}

We used the Pyrococcus abyssi Orsay strain, from which the total genome sequencing was performed by Genoscope (Evry, France). E. coli DH5 $\alpha$ and HMS174(DE3) were purchased from Clontech Laboratories (Basingstoke, UK) and Novagen (Madison, WI), respectively. Deoxyribonucleoside 5'-triphosphates, $\left[\alpha-{ }^{32} \mathrm{P}\right]$ $\operatorname{dCTP}(3,000 \mathrm{Ci} / \mathrm{mmol})$ and $\left[\gamma_{-}{ }^{32} \mathrm{P}\right] \mathrm{ATP}(5,000 \mathrm{Ci} / \mathrm{mmol})$ were obtained from Amersham Pharmacia Biotech (Saclay, France). Polyacrylamide gel electrophoresis (PAGE) reagents were purchased from BioRad, Ivry sur Seine, France. Source Q was obtained from Amersham Pharmacia Biotech and hydroxyapatite 'high resolution' was purchased from Fluka (Buchs, Switzerland). All other chemicals were molecular biology grade reagents from Sigma-Aldrich (St.Louis, USA).

\section{Enzymes and proteins}

T4 DNA ligase, modification enzymes and restriction enzymes were obtained from Roche-Diagnostics (Mannheim, Germany). The phosphorylable derivative of human PCNA (ph-PCNA) was obtained as previously described ${ }^{42}$. The modified PCNA contains 18 additional amino acids at the C-terminus, which generate a phosphorylation site for heart muscle protein kinases. The catalytic subunit of the non-cyclic AMPdependent protein kinase from bovine heart muscle was purchased from Sigma-Aldrich.

\section{Nucleic acids}


Single-stranded circular (ssc) M13mp18 DNA was obtained from Amersham Pharmacia Biotech. Singly primed M13mp18ssc was prepared by incubating $125 \mu \mathrm{l}$ of M13mp18ssc $(0.2 \mathrm{mg} / \mathrm{ml})$ with $2 \mu \mathrm{l}$ of a complementary oligonucleotide primer (M13prim) (5'-ATTCGTAATCATGGTCATAGCTGTTTCCTG-3') (1 mg/ml) and $125 \mu \mathrm{l}$ of annealing buffer: $20 \mathrm{mM}$ Tris- $\mathrm{HCl}(\mathrm{pH} 7.8), 5 \mathrm{mM} \mathrm{MgCl} 2,250 \mathrm{mM} \mathrm{NaCl}$. The reaction mixture was heated at $75^{\circ} \mathrm{C}$ for 15 minutes and then slowly cooled to room temperature.

\section{Buffers}

Buffer A: $50 \mathrm{mM}$ Tris-HCl (pH 8.0), $0.1 \mathrm{mM}$ EDTA, $2 \mathrm{mM} \beta$-mercaptoethanol, 10\% (v/v) glycerol; Buffer B: 50 mM Tris-HCl (pH 7.5), 0.1 mM EDTA, 1 mM DTT, 10\% (v/v) glycerol; Buffer C: 25 mM potassium phosphate (pH 7.5), 1 mM DTT, 500 $\mathrm{mM} \mathrm{NaCl}, 10 \%$ (v/v) glycerol; Buffer D: 0.3 M potassium phosphate (pH 7.5), 1 mM DTT, 500 mM NaCl, 10\% (v/v) glycerol; Buffer E: 50 mM Tris-HCl (pH 7.5), 1 mM DTT, $0.1 \mathrm{mM}$ EDTA, $0.5 \mathrm{M} \mathrm{NaCl}, 10 \%$ (v/v) glycerol; Buffer F: 20 mM Tris-HCl (pH 6.8), 1 mM DTT, 0.1 mM EDTA, 10\% (v/v) glycerol; Buffer G: 10 mM Tris-HCl (pH 6.8), 1 mM DTT, 300 mM NaCl, 5\% (v/v) glycerol; Buffer H: 10 mM Tris-HCl (pH 6.8), $1 \mathrm{mM}$ DTT, $1 \mathrm{M} \mathrm{MgCl}_{2}$, 5\% (v/v) glycerol; Buffer I: $10 \mathrm{mM}$ Tris- $\mathrm{HCl}$ (pH 6.8), $1 \mathrm{mM}$ DTT, $50 \mathrm{mM} \mathrm{NaCl}$, 5\% (v/v) glycerol; Buffer J: 10 mM Tris-HCl (pH 6.8), 1 mM DTT, $50 \mathrm{mM} \mathrm{NaCl}, 250 \mathrm{mM}$ potassium phosphate (pH 6.8).

\section{Computer analysis of protein sequences}


Protein and gene sequences were retrieved from the NCBI Entrez sequence database. Multiple sequence alignments were produced using the ClustalW program ${ }^{62}$.

\section{Cloning of the Pyrococcus abyssi RFC genes}

(i) RFC-small encoding the small subunit (accession number PAB0068; NP 125803)

The inteins were removed by the splicing overlap extension strategy ${ }^{63}$. Briefly, internal and external oligonucleotide primers were designed to amplify the gene encoding the PabRFC-small subunit from Pyrococcus abyssi. External oligonucleotide primers RF1ini (forward) (5'-GGCCTCTAATTTCATATGCGTGACATGGAG-3') and RF1end (reverse) (5'-ATGGGTCGGATCCTTATTTCTTCTTTCCGAT-3') were designed to contain the NdeI and BamHI restriction sites, respectively (underlined). The NdeI site contains the initiation codon ATG. Therefore, the Val that is given as the initiator amino acid in the annotated genome was mutated to Met. The BamHI site is immediately after the stop codon. Internal oligonucleotide primers were designed to be completely homologous to the RFC-small gene:

Int1-2 (reverse): 5'-AGGGCCAGAGCGGCGGTTGTCTTTCCAACTCCTGGGGGCC3'; Int3-4 (forward): 5'GGCCCCCAGGAGTTGGAAAGACAACCGCCGCTCTGGCCCT-3’; Int5-6 (reverse): 5'-ATCTTTGACGAATAGTTGCAGCTTAAAATAAACCTTACGT3'; 
Int7-8 (forward): 5' -ACGTAAGGTTTATTTTAAGCTGCAACTATTCGTCAAAGAT3'.

The entire RFC-small subunit (993 bp) was obtained by fragment complementation after three rounds of $\mathrm{PCR}\left(90^{\circ} \mathrm{C}, 1\right.$ minute; $50^{\circ} \mathrm{C}, 1$ minute; $72^{\circ} \mathrm{C}, 1$ minute; 10 cycles, DyNAzyme EXT DNA polymerase from Finnzymes, Espoo, Finland). The region was cloned and sequenced by the dideoxy chain termination method.

The PCR-amplified RFC-small subunit was digested with NdeI and BamHI and ligated into the $N d e \mathrm{I}-\mathrm{BamHI}$ sites of linearized pET11a E. coli ampicillin resistant vector. The final product was called pRFC-small.

(ii) RFC-large encoding the large subunit (accession number PAB0069; NP 125804)

The RFC-large gene from Pyrococcus abyssi was amplified from genomic DNA. The PCR-primers were as follows: RF2ini (forward) (5'-ATAAAGTGATGACATATGCCAGAAGTTCCC-3') and RF2end (reverse) (5'-GGCCCTACTGGATCCAGCTACTTCTTTATG-3'). These primers contained NdeI and BamHI restriction sites (underlined), respectively. The PCR product (1440 bp) was cloned into the NdeI-BamHI sites of linearized pET26b(+) E. coli kanamycin resistant vector. The final product was called pRFC-large. The integrity of the insert was confirmed by DNA sequencing.

\section{Production and purification of recombinant $\mathrm{PabRF}$ proteins}

Both pRFC-small and pRFC-large constructs containing the bacteriophage T7 gene promoter and leader sequence were introduced into E. coli strain MC1061(DE3) provided by J.M. Masson (IBPS, Toulouse, France). E. coli MC1061(DE3) harboring pRFC-small 
and pRFC-large were grown at $37^{\circ} \mathrm{C}$ in 3 liters of LB medium with ampicillin (100 $\mu \mathrm{g} / \mathrm{ml})$ and kanamycin $(30 \mu \mathrm{g} / \mathrm{ml})$. The cells were grown to an O.D. $600 \mathrm{~nm}$ of 0.8 and then a final concentration of $0.6 \mathrm{mM}$ IPTG was added to induce the overproduction of the recombinant proteins. The cells were cultured for further 4 hours with gentle shaking (150 rpm). Then, they were centrifuged and the pellet was resuspended in $50 \mathrm{ml}$ of buffer A. Bacterial lysates were prepared by sonication ( $30 \times 2$ s pulses then 2 x $30 \mathrm{~s}$ pulses). Cellular debris were removed by centrifugation at $15,000 \mathrm{xg}$ for 45 minutes at $4{ }^{\circ} \mathrm{C}$, and the pellet was resuspended in $20 \mathrm{ml}$ of buffer A and subjected to a second round of sonication. After centrifugation, the two supernatants were pooled $(65 \mathrm{ml}$; protein concentration: $4.2 \mathrm{mg} / \mathrm{ml}$ ) and heated at $75^{\circ} \mathrm{C}$ for 15 minutes, followed by centrifugation $\left(15,000 \mathrm{x} \mathrm{g} ; 45\right.$ minutes, $\left.4^{\circ} \mathrm{C}\right)$. The supernatant $(59 \mathrm{ml}$; protein concentration: $1 \mathrm{mg} / \mathrm{ml})$ was heated for 10 minutes at $80^{\circ} \mathrm{C}$ and clarified by centrifugation for 45 minutes at $15,000 \mathrm{x}$ g. The supernatant ( $55 \mathrm{ml}$; protein concentration: $1 \mathrm{mg} / \mathrm{ml}$ ) was divided into two equal fractions, $\mathrm{A}$ and $\mathrm{B}$, and subjected to two different purification protocols as outlined below:

Fraction A (27.5 ml) was put through an anion-exchange column (Source Q, $16 \mathrm{~mm} \mathrm{x}$ $7.5 \mathrm{~cm})(1 \mathrm{ml} /$ minute) pre-equilibrated with buffer $\mathrm{B}$. The column was washed with 80 $\mathrm{ml}$ of buffer B and the proteins were eluted with a $90 \mathrm{ml}$ linear gradient from buffer B to buffer B containing $1 \mathrm{M} \mathrm{NaCl}$. Two $\mathrm{ml}$ fractions were collected and analyzed by SDSPAGE. The fractions containing the RFC complex (centered at $0.2 \mathrm{M} \mathrm{NaCl}$ ) were pooled (6.5 ml; protein concentration: $0.7 \mathrm{mg} / \mathrm{ml})$ and loaded onto a hydroxyapatite column $(0.5$ $\mathrm{ml} /$ minute) $(16 \mathrm{~mm} \times 9.5 \mathrm{~cm})$ pre-equilibrated with buffer C. The column was washed 
with $40 \mathrm{ml}$ of buffer $\mathrm{C}$ and proteins were eluted with a $70 \mathrm{ml}$ linear gradient from buffer $\mathrm{C}$ to buffer $\mathrm{D}$ ( $2 \mathrm{ml}$ fractions). Fractions that contained the pure recombinant protein (15 $\mathrm{ml}$; protein concentration: $0.4 \mathrm{mg} / \mathrm{ml}$; centered at $180 \mathrm{mM}$ potassium phosphate) were pooled.

Fraction $\boldsymbol{B}(27.5 \mathrm{ml})$ was adjusted to $1 \mathrm{M} \mathrm{NaCl}$ by adding $50 \mathrm{mM}$ Tris- $\mathrm{HCl}$ (pH 8.0), 1 mM DTT, $0.1 \mathrm{mM}$ EDTA, $4 \mathrm{M} \mathrm{NaCl}, 10 \%$ (v/v) glycerol, and nucleic acids were precipitated by adding Polymin P to a final concentration of $0.2 \%$, under gentle agitation for 10 minutes at room temperature. After centrifugation $(15,000 \mathrm{x} g, 45$ minutes $)$, the supernatant was collected and solid ammonium sulfate was added over a period of $1 \mathrm{~h}$, at $0^{\circ} \mathrm{C}$, to obtain a $80 \%$ ammonium sulfate saturation. The mixture was further stirred for 1 hour and centrifuged at 15,000 $\mathrm{x} g$ for $1 \mathrm{~h}$. The resulting pellet was washed with $18 \mathrm{ml}$ of $50 \mathrm{mM}$ Tris- $\mathrm{HCl}$ (pH 7.5), $1 \mathrm{mM}$ DTT, $0.1 \mathrm{mM}$ EDTA, $0.5 \mathrm{M} \mathrm{NaCl}$, ammonium sulfate to $80 \%$ saturation, and centrifuged $\left(15,000 \mathrm{x} \mathrm{g} ; 1 \mathrm{~h}, 4^{\circ} \mathrm{C}\right)$. The pellet was resuspended in $5 \mathrm{ml}$ of buffer $\mathrm{E}$ and dialyzed twice against 1.5 liters of buffer $\mathrm{E}$. The fraction was then subjected to phosphocellulose chromatography on a $26 \mathrm{~mm} \times 12 \mathrm{~cm}$ column equilibrated with buffer $\mathrm{E}(0.5 \mathrm{ml} / \mathrm{minute}, 2 \mathrm{ml}$ fractions $)$. Fractions containing protein were pooled (20 ml; protein concentration: $0.5 \mathrm{mg} / \mathrm{ml}$ ) and subjected to hydroxyapatite column chromatography as described for fraction A. Finally, the fraction containing the pure recombinant protein $(13.5 \mathrm{ml}$; protein concentration: $0.4 \mathrm{mg} / \mathrm{ml})$ were pooled.

Fractions A and B containing the RFC complex were concentrated by centrifugation on a Centriprep 10 device (Millipore, Molsheim, France), and stored at - 
$80^{\circ} \mathrm{C}$ after dialysis against $20 \mathrm{mM}$ Tris- $\mathrm{HCl}(\mathrm{pH} 7.5), 2 \mathrm{mM}$ DTT, $0.5 \mathrm{mM}$ EDTA, $0.5 \mathrm{M}$ $\mathrm{NaCl}, 10 \%(\mathrm{v} / \mathrm{v})$ glycerol. The final yield of recombinant proteins purified by these two protocols was about 3-5 mg per liter of bacterial culture.

\section{Production and purification of the recombinant PabRFC-small subunit}

E. coli HMS174(DE3) containing the pRFC-small construct was grown to an O.D.600 nm of 0.6 at $37^{\circ} \mathrm{C}$ in 1.5 liters of $2 x Y T$ broth with ampicillin $(100 \mu \mathrm{g} / \mathrm{ml})$. The overproduction of the recombinant protein was induced by adding IPTG to a final concentration of $1 \mathrm{mM}$. The cells were cultured for a further 3.5 hours and pelleted by centrifugation. They were resuspended in $25 \mathrm{ml}$ of buffer A and subjected to the sonication protocol as described for the RFC fraction A, including a second round of sonication with $10 \mathrm{ml}$ of buffer A. After centrifugation (15,000 x g for $45 \mathrm{~min})$, the supernatant $(35 \mathrm{ml}$; protein concentration: $9.8 \mathrm{mg} / \mathrm{ml})$ was heated at $75^{\circ} \mathrm{C}$ for $15 \mathrm{~min}$, followed by centrifugation $(30 \mathrm{ml}$; protein concentration: $1.5 \mathrm{mg} / \mathrm{ml})$ and at $80^{\circ} \mathrm{C}$ for 10 $\min (29 \mathrm{ml}$; protein concentration: $1.3 \mathrm{mg} / \mathrm{ml})$. After chromatography on Source Q $(9.3$ $\mathrm{ml}$; protein concentration: $0.6 \mathrm{mg} / \mathrm{ml}$; centered at $0.1 \mathrm{M} \mathrm{NaCl})$ and hydroxyapatite $(3 \mathrm{ml}$; protein concentration: $0.4 \mathrm{mg} / \mathrm{ml}$; centered at $100 \mathrm{mM}$ potassium phosphate), the fractions containing the pure recombinant $P a b$ RFC-small were pooled and concentrated as described for PabRFC-complex. The final yield was about $0.8 \mathrm{mg}$ per liter of bacterial culture.

\section{Cloning of Pyrococcus abyssi PCNA gene (PabPCNA)}


PCR was used to amplify the ORF encoding for the putative PCNA (accession number, PAB1465; NP 127054) from Pyrococcus abyssi. Two primers were designed to introduce a $N d e$ I site at the initiating methionine and a $B g l I I$ site just next to the stop codon, respectively (underlined):

PCNAini (forward) (5'-AGGTGCAAACATATGCCATTCGAGATAGTC-3') and PCNAend (reverse) (5'-AGTTAA

The PCR product was digested with NdeI and BglII and ligated into the NdeIBamHI site of the E. coli expression vector pET26b(+) containing the bacteriophage T7 gene promoter and leader sequence. The identity of the gene was confirmed by nucleotide sequencing and the recombinant plasmid was designated $\mathrm{pPabPCNA.}$

\section{Production and purification of the recombinant PabPCNA}

Recombinant E. coli HMS174(DE3) containing pPabPCNA were grown to an O.D.600 nm of 0.6 in 1.5 liters of LB medium containing kanamycin $(30 \mu \mathrm{g} / \mathrm{ml})$ with gentle shaking $(150 \mathrm{rpm})$. A final concentration of $1 \mathrm{mM}$ of IPTG was then added. Five hours after induction, the cells were harvested, resuspended in $25 \mathrm{ml}$ of $50 \mathrm{mM}$ Tris- $\mathrm{HCl}$ (pH 8.5), $0.1 \mathrm{mM}$ EDTA, $2 \mathrm{mM} \beta$-mercaptoethanol, $0.1 \mathrm{M} \mathrm{NaCl}, 10 \%$ (v/v) glycerol, and lysed by sonication ( $10 \times 2 \mathrm{~s}$ pulses then $2 \times 30 \mathrm{~s}$ pulses). Cellular debris were removed by centrifugation at $15,000 \mathrm{x}$ g for 45 minutes at $4{ }^{\circ} \mathrm{C}$. E. coli proteins present in the supernatant ( $25 \mathrm{ml}$; protein concentration: $4.5 \mathrm{mg} / \mathrm{ml})$ were partially eliminated by two heat treatment steps, as described for RFC, and the resulting supernatant was dialyzed against buffer F. The solution $(30 \mathrm{ml}$; protein concentration: $0.6 \mathrm{mg} / \mathrm{ml}$ ) was then passed through an anion-exchange column ( $1 \mathrm{ml} /$ minute) (Source Q, $16 \mathrm{~mm} \times 10 \mathrm{~cm}$ ) pre- 
equilibrated with buffer $\mathrm{F}$. The proteins were eluted with a $90 \mathrm{ml}$ linear gradient of buffer F to buffer $\mathrm{F}$ containing $1 \mathrm{M} \mathrm{NaCl}$ ( $2 \mathrm{ml}$ fractions). The fractions containing PabPCNA (detected by SDS-PAGE) were pooled $(12 \mathrm{ml}$; protein concentration: $0.7 \mathrm{mg} / \mathrm{ml}$; centered at $0.4 \mathrm{M} \mathrm{NaCl})$ and loaded onto an hydroxyapatite column $(0.5 \mathrm{ml} / \mathrm{minute})(16 \mathrm{~mm} \times 9.5$ $\mathrm{cm}$ ) pre-equilibrated with buffer $\mathrm{G}$. The column was washed with $40 \mathrm{ml}$ of buffer $\mathrm{G}$, followed by $40 \mathrm{ml}$ of buffer $\mathrm{H}$, and finally the $P a b$ PCNA was eluted with a $60 \mathrm{ml}$ linear gradient from buffer I to buffer J. One $\mathrm{ml}$ fractions were collected. The fractions containing the PabPCNA ( $10.5 \mathrm{ml}$; protein concentration: $0.14 \mathrm{mg} / \mathrm{ml}$; centered at $0.2 \mathrm{M}$ potassium phosphate) were concentrated, dialyzed against $50 \mathrm{mM}$ Tris-HCl, (pH 8.0), 1 $\mathrm{mM}$ DTT, $0.1 \mathrm{mM}$ EDTA, $50 \%(\mathrm{v} / \mathrm{v})$ glycerol and stored at $-20^{\circ} \mathrm{C}$. The final yield was about $1 \mathrm{mg}$ per liter of bacterial culture.

\section{Terminal sequence analysis}

The RFC subunits were subjected to electrophoresis in $12 \%$ SDS gels, then transferred onto PVDF membranes. Finally, the sequences of the N-termini of both RFC subunits were determined.

\section{Western blotting}

E. coli HMS174(DE3) harboring pRFC-large was grown to an O.D.600 nm of 0.4 in $50 \mathrm{ml} \mathrm{LB}$ containing kanamycin $(30 \mu \mathrm{g} / \mathrm{ml})$ at $37^{\circ} \mathrm{C}$. IPTG was then added to the culture at a final concentration of $1 \mathrm{mM}$ and growth was continued for $4 \mathrm{~h}$. Cells were harvested by centrifugation for 15 minutes at $6000 \mathrm{rpm}$. The pellet was resuspended in buffer $\mathrm{A}$ and the total extract was used for immunoblot analysis. The proteins were separated on $10 \%$ 
SDS-PAGE and transferred to nitrocellulose membranes. The blots were saturated with blocking buffer containing 5\% (w/v) skimmed milk in TBS-T (Tris Buffer Saline: $10 \mathrm{mM}$ Tris- $\mathrm{HCl}(\mathrm{pH} 7.5), 150 \mathrm{mM} \mathrm{NaCl}$ and $0.05 \%$ (v/v) Tween 20) for 30 minutes. The blots were then incubated for two hours at room temperature with either a 1:5000 dilution of the rabbit polyclonal anti-human RFC PCNA-binding domain region antibody (produced at the animal facility in the Institute of Animal Breeding of the University of Zürich) or a 1:1000 dilution of the mouse monoclonal anti-human RFC DNA-binding domain region antibody ${ }^{39}$ in TBS-T with $2 \%(\mathrm{w} / \mathrm{v})$ skimmed milk. The membranes were washed three times with TBS-T, and then incubated for two hours at room temperature with a 1:5000 dilution of horseradish peroxidase-conjugated anti-rabbit antibody or 1:10000 dilution of horseradish peroxidase-linked anti-mouse IgG in $2 \%(\mathrm{w} / \mathrm{v})$ skimmed milk in TBS-T. The membranes were washed three times with TBS-T and the secondary antibody was detected by the enhanced chemiluminescence system (SuperSignal® West Pico Chemiluminescent Substrate, Pierce, Rockford, Ill., USA) according to the manufacturer's instructions.

\section{Protein quantification}

Protein concentrations were determined by the Bradford method ${ }^{64}$ using the Biorad reagent and bovine serum albumin as the standard.

\section{Analytical gel filtration}

To estimate the molecular mass of the RFC complex, purified RFC fractions were subjected to gel filtration analysis using an Amersham Pharmacia FPLC system. A 
Superdex-200 HR 10/30 column (Amersham Pharmacia) was pre-equilibrated with 50 mM Tris- $\mathrm{HCl}$ (pH 8.0), 1 mM DTT, 0.1 mM EDTA, 10\% (v/v) glycerol. The flowrate was $0.5 \mathrm{ml} /$ minute. Thyroglobulin (669 kDa), ferritin (440 kDa), aldolase (158 kDa), ribonuclease A (137 kDa), bovine serum albumin $(67 \mathrm{kDa})$ and chicken ovalbumin (43 $\mathrm{kDa}$ ) were used as molecular weight markers.

\section{ATPase activity assays}

The standard reaction mixture $(20 \mu \mathrm{l})$ contained $20 \mathrm{mM}$ HEPES-NaOH (pH 7.5), 2 $\mathrm{mM}$ DTT, $50 \mu \mathrm{g} / \mathrm{ml}$ bovine serum albumin, $3 \mathrm{mM} \mathrm{MgCl} 2,100 \mathrm{mM} \mathrm{NaCl}, 50 \mu \mathrm{M}$ ATP, 4 pmol of $\left[\gamma_{-}^{-32}\right]$ ATP (specific activity, $5000 \mathrm{Ci} / \mathrm{mmol}$ ), $15 \mu \mathrm{M}$ primed M13ssc DNA (nucleotide concentration) and different amounts of recombinant proteins as indicated in the figure legends. The reaction mixtures were incubated for 30 minutes at $60^{\circ} \mathrm{C}$ and the reaction quenched on ice by adding $10 \mu \mathrm{l}$ of $30 \mathrm{mM}$ EDTA. Two $\mu 1$ of the products were separated by polyethyleneimine-cellulose TLC (Merck, Darmstadt, Germany) in $0.5 \mathrm{M}$ $\mathrm{LiCl} / 1 \mathrm{M}$ formic acid. The amount of inorganic phosphate produced was then quantified by scanning the autoradiography plates.

\section{Agarose gel electrophoresis of ph-PCNA-PabRFC-DNA complexes.}

The human PCNA derivative (ph-PCNA) was labeled by incubation with $[\gamma-$

$\left.{ }^{32} \mathrm{P}\right] \mathrm{ATP}$ and the bovine heart muscle protein kinase $(0.15 \mathrm{unit} / \mu \mathrm{l})$ as previously described ${ }^{42}$. The $\left[{ }^{32} \mathrm{P}\right]$ ph-PCNA-PabRFC-DNA complex was assembled in $20 \mathrm{mM}$ Hepes- $\mathrm{NaOH}$ (pH 7.5), $2 \mathrm{mM}$ DTT, $0.2 \mathrm{mg} / \mathrm{ml}$ bovine serum albumin, $3 \mathrm{mM} \mathrm{MgCl}, 0.1$ $\mathrm{M} \mathrm{NaCl}$, in the presence of $4 \mathrm{ng} / \mu \mathrm{l}$ of primed M13ssc heteroduplex (total volume: $25 \mu \mathrm{l}$ ). 
Concentrations of $P a b$ RFC and ph-PCNA were $20 \mathrm{ng} / \mu \mathrm{l} . P a b$ RFC was pre-incubated at $65^{\circ} \mathrm{C}$ for 10 minutes and subsequently added to the reaction mixture, followed by incubation at $45^{\circ} \mathrm{C}$ for 3 minutes. Then, $2.5 \mu \mathrm{l}$ of $1 \%$ (wt/vol) glutaraldehyde was added and the mixture was further incubated at $37^{\circ} \mathrm{C}$ for $10 \mathrm{~min}$. Finally, $0.8 \%$ agarose gel electrophoresis were performed, in the presence of $0.1 \%$ (wt/vol) SDS, as previously described, ${ }^{42}$.

\section{DNA synthesis studies with PabDNA pol II.}

To determine the stimulation, by the PabRFC, of the primer-extension abilities of the family D Pab DNA polymerase, 1 unit of PabPol II was incubated in $20 \mathrm{mM}$ Bis-Tris (pH 6.5), $2 \mathrm{mM} \beta$-mercaptoethanol, $0.4 \mathrm{mg} / \mathrm{ml}$ bovine serum albumin, $10 \mathrm{mM} \mathrm{MgCl}_{2}, 0.2$ $\mathrm{mM}$ of each of the dNTPs, $60 \mu \mathrm{Ci} / \mathrm{ml}$ of $\left[\alpha^{32} \mathrm{P}\right] \mathrm{dCTP}, 12.5 \mu \mathrm{g}$ of primed M13ssc, $0.5 \mathrm{mM}$ ATP, $100 \mathrm{ng}$ of $\mathrm{PabPCNA}$ and $500 \mathrm{ng}$ of $\mathrm{PabRFC}$. The reaction mixture $(50 \mu \mathrm{l})$ was incubated at $65^{\circ} \mathrm{C}$ for 30 minutes. $\mathrm{NaOH}(30 \mathrm{mM})$ and EDTA $(1 \mathrm{mM})$ were then added and the reaction mixture analyzed by denaturing agarose gel (1\%) electrophoresis and autoradiography. One unit of Pol II corresponds to $1 \mathrm{nmol}$ of dNTP incorporated into acid-insoluble materials, at $65^{\circ} \mathrm{C}$ in 1 minute using poly(dA)/oligo(dT) as substrate. 
Figure 1. Physical map of the Pyrococcus abyssi origin of replication locus containing the RFC genes PAB0068 and PAB0069.

The putative genes encoding the helicase and Rad51 protein are indicated. The family D DNA polymerase, encoded by two subunits, and a putative initiation factor (Orc1) were identified upstream of the P. abyssi candidate origin of replication ${ }^{38}$. PabRFC-small and PabRFC-large are arranged in tandem, in an operon (5765 bp). The putative transcription and translation signals are shown at the bottom: from left to right, a putative eukaryoticlike TATA-box, a putative prokaryotic-like Shine-Dalgarno motif (SD), the PabRFCsmall gene start and stop codons, the PabRFC-large gene start codon, and the putative eukaryotic-like transcription termination sequence (polypyrimidine stretches). Archaealspecific genes are shown in black, bacterial-specific genes in grey, and eukaryotic-like

genes are dashed ${ }^{38}$. 0066: alanyl-tRNA synthetase gene; 2264: methylthioadenosine phosphorylase gene; 2273: molybdenum cofactor biosynthesis protein gene; 2277: IMP dehydrogenase gene; 2278: lacZ expression regulatory protein gene. Genes 0070, 0071, 2269, 2271, 2272 and 3032 code for hypothetical proteins.

\section{Figure 2. Comparison of archaeal and eukaryotic RFC subunits.}

A. Conserved RFC boxes among PabRFC and human RFC. The corresponding regions are numbered on the top of the panel. The length in amino acids is shown on the right. The RFC box that includes box IV is indicated at the bottom. The arrows map the DNA binding domain [369-480] and the PCNA-binding domain [481-728] in the hRFC 140. B. Amino acid sequence similarities within the RFC boxes. MthRFC (from Methanobacterium thermoautotrophicum), SsoRFC (from Sulfolobus solfataricus) and 
hRFC (from human) were compared to the PabRFC. The P-loop and DEAD-box are

indicated. C. Structure of the active forms of RFC complexes from human ${ }^{40}$, Methanobacterium thermoautotrophicum ${ }^{36}$, Sulfolobus solfataricus ${ }^{34}$ and Pyrococcus furiosus ${ }^{35}$.

Figure 3. Coexpression of the PabRFC subunits in E. coli produced a stable soluble complex.

Purification of PabRFC subunits was performed as outlined in "Materials and Methods". Soluble proteins from each step of purification were separated by $12 \%$ SDS-PAGE. Visualization was achieved by staining with Coomassie Brillant Blue. Lanes: 1, Low Molecular Weight markers (Pharmacia biotech); 2, induced cells (90 $\mu \mathrm{g}) ; 3$, extract after heat treatment (16 $\mu \mathrm{g}) ; 4$, purified PabRFC complex (58 $\mu \mathrm{g})$ (see "Materials and Methods"). The PabRFC-large and PabRFC-small subunits migrated at the expected sizes in agreement with the expected mass of $55 \mathrm{kDa}$ and $38 \mathrm{kDa}$, respectively.

Figure 4. Analytical gel permeation chromatography of the purified PabRFC complex.

PabRFC was subjected to FPLC on a Superdex 200 HR column as described in "Materials and Methods". The flow-rate was of $0.5 \mathrm{ml} /$ minute and the molecular weight standards were: 1 . Thyroglobulin (669 kDa); 2. Ferritin (440 kDa); 3. Aldolase (158 kDa), 4. Ribonuclease A (137 kDa), 5. Bovine Serum Albumin (67 kDa); 6. Chicken Ovalbumin $(43 \mathrm{kDa})$. The experiment was made with the $P a b R F C$-complex purified by protocole A (see "Materials and Methods") 


\section{Figure 5. Anti-hRFC p140 PCNA-binding domain antibody cross-reacts with the PabRFC-large subunit.}

The soluble and insoluble fractions of the recombinant PabRFC-large were analyzed by SDS-PAGE and the gels were subsequently subjected to immunoblot experiments using antibodies against either the DNA-binding domain (left) (240 ng) or the PCNA-binding domains (right) (437.5 ng) of hRFC p140 (see also Figure 2). The positive controls used were the full-length recombinant hRFC p140 protein (left) and the recombinant PCNAbinding domain of hRFC p140 protein (right). Lane 1, crude pellet; lane 2, crude

supernatant; lane 3, uninduced cells (negative control) (E. coli crude extracts: $114 \mu \mathrm{g}$ ). Sizes are indicated as $\mathrm{kDa}$ on the left of the figures.

\section{Figure 6. Characterization of the ATPase activity of recombinant PabRFC.} ATPase assays were performed with $15 \mu \mathrm{M}$ (nucleotide concentration) of the circular M13ssc DNA heteroduplex as described in "Materials and Methods". a. DNAindependent ATPase activity of the PabRFC-complex; b. DNA-independent ATPase activity of PabRFC-small; Reactions were carried out either in the absence (open symbols) or in the presence (solid symbols) of the DNA heteroduplex.

c. DNA-dependent stimulation of PabRFC-complex ATPase activity by PabPCNA; d. DNA- and PCNA-independent ATPase activity of PabRFC-small; PabRFC and PabRFC-small amounts were $50 \mathrm{ng}$ (circles) or $250 \mathrm{ng}$ (squares), in the absence (open symbols) or presence (closed symbols) of the DNA heteroduplex. 
Experiments were made with PabRFC-complexes purified with protocols A and B (see "Materials and Methods").

Figure 7. Stimulation of PabRFC ATPase activity by hPCNA is dependent on DNA. The experimental conditions were as described in the legend to Figure 6 and in "Materials and Methods", excepted that the incubation temperature was $45^{\circ} \mathrm{C}$. A. The incubations were performed in the absence (open symbols) or presence (solid symbols) of primed M13ssc, either in the absence (circles) or presence (squares) of hPCNA (12.5 ng/ $\mu 1)$; B. Stimulation of the PabRFC ATPase activity by PabPCNA is dependent on DNA. Open circles, no DNA; solid circles, primed M13ssc. PabRFC was $25 \mathrm{ng} / \mu \mathrm{l}$. The PabRFC-complex was purified by using protocol A (see "Materials and Methods").

Figure 8. Effect of $P a b$ RFC on the PabPCNA-dependent primer-extension by

\section{PabPol II.}

One unit of PabPol II was incubated, as indicated in "Materials and Methods", with 100 ng of $P a b \mathrm{PCNA}$ and $500 \mathrm{ng}$ of $\mathrm{PabRFC}$. The reaction mixture was incubated at $65^{\circ} \mathrm{C}$ for 30 minutes and subjected to agarose gel electrophoresis and autoradiography. The arrow indicates the position of the full length M13 DNA. PabRFC-complexes purified by protocols A and B (see "Materials and Methods") were used.

Figure 9. PabRFC can load hPCNA onto a primed circular DNA in the presence of non-hydrolyzable ATP. 
The reaction conditions were as outlined in "Materials and Methods". The reaction mixture $(25 \mu \mathrm{l})$ contained $1 \mathrm{mM}$ ATP or ATP- $\gamma-\mathrm{S}, 500 \mathrm{ng}\left[{ }^{32} \mathrm{P}\right] \mathrm{ph}-\mathrm{PCNA}$ and $500 \mathrm{ng}$ PabRFC and DNA: lane 1, M13ssc + ATP (control without PabRFC); lane 2, M13ssc + ATP and PabRFC; lane 3, M13ds, no ATP and PabRFC; lane 4, M13ssc, no ATP and PabRFC; lane 5, M13ssc + ATP- $\gamma-\mathrm{S}$ and PabRF.

The PabRFC-complex used was purified by protocol A (see "Materials and Methods"). 


\section{References}

1. Kelman, Z. \& O'Donnell, M. (1994). DNA replication : enzymology and mechanisms. Curr. Opin. Genet. Dev. 4, 185-195.

2. Waga, S. \& Stillman, B. (1998). The DNA replication fork in eukaryotic cells. Ann. Rev. Biochem. 67, 721-751.

3. Alley, S. C., Abel Santos, E. \& Benkovic, S. J. (2000). Tracking sliding clamp opening and closing during bacteriophage T4 DNA polymerase holoenzyme assembly. Biochemistry USA 39, 3076-3090.

4. Bertram, J. G., Bloom, L. B., Hingorani, M. M., Beechem, J. M., O'Donnell, M. \& Goodman, M. F. (2000). Molecular mechanism and energetics of clamp assembly in Escherichia coli - The role of ATP hydrolysis when $\gamma$ complex loads $\beta$ on DNA. $J$. Biol. Chem. 275, 28413-28420.

5. Salinas, F. \& Benkovic, S. J. (2000). Characterization of bacteriophage T4-coordinated leading- and lagging-strand synthesis on a minicircle substrate. Proc. Natl. Acad. Sci. USA 97, 7196-7201.

6. Gomes, X. V. \& Burgers, P. M. J. (2001). ATP utilization by yeast replication factor C. I. ATP-mediated interaction with DNA and with Proliferating cell nuclear antigen. $J$. Biol. Chem. 276, 34768-34775.

7. Gomes, X. V., Schmidt, S. L. G. \& Burgers, P. M. J. (2001). ATP utilization by yeast replication factor C. II. Multiple stepwise ATP-binding events are required to load Proliferating cell nuclear antigen onto primed DNA. J. Biol. Chem. 276, 3477637783. 
8. Schmidt, S. L. G., Gomes, X. V. \& Burgers, P. M. J. (2001). ATP utilization by yeast replication factor C. III. The ATP-binding domains of $\mathrm{Rfc} 2, \mathrm{Rfc} 3$, and $\mathrm{Rfc} 4$ are essential for DNA recognition and clamp loading. J. Biol. Chem. 276, 34784-34791.

9. Schmidt, S. L. G., Pautz, A. L. \& Burgers, P. M. J. (2001). ATP utilization by yeast replication factor C. IV. RFC ATP-binding mutants show defects in DNA replication, DNA repair and checkpoint regulation. J. Biol. Chem. 276, 34792-348010.

10. Jeruzalmi, D., Yurieva, O., Zhao, Y. X., Young, M., Stewart, J., Hingorani, M., M, O. D. \& Kuriyan, J. (2001). Mechanism of processivity clamp opening by the delta subunit wrench of the clamp loader complex of E-coli DNA polymerase III. Cell 106, 417-428.

11. O'Donnell, M., Onrust, R., Dean, F. B., Chen, M. \& Hurwitz, J. (1993). Homology in accessory proteins of replicative polymerases - E. coli to humans. Nucleic Acids Res. 21, 1-3.

12. Prelich, G., Kostura, M., Marshak, D. R., Mathews, M. B. \& Stillman, B. (1987). The cell-cycle regulated proliferating cell nuclear antigen is required for SV40 DNA replication in vitro. Nature 326, 471-475.

13. Hindges, R. \& Hübscher, U. (1997). DNA polymerase $\delta$, an essential enzyme for DNA transactions. Biol. Chem. 378, 345-362.

14. Maga, G. \& Hübscher, U. (1995). DNA polymerase epsilon interacts with proliferating cell nuclear antigen in primer recognition and elongation. Biochemistry USA 34, 891-901. 
15. Podust, V. N., Georgaki, A., Strack, B. \& Hübscher, U. (1992). Calf thymus RF-C as an essential component for DNA polymerase $\delta$ and $\varepsilon$ holoenzymes function. Nucleic Acids Res. 20, 4159-4165.

16. Cai, J. S., Yao, N. N., Gibbs, E., Finkelstein, J., Phillips, B., O'Donnell, M. \& Hurwitz, J. (1998). ATP hydrolysis catalyzed by human replication factor C requires participation of multiple subunits. Proc. Natl. Acad. Sci. USA 95, 11607-11612.

17. Podust, V. N., Tiwari, N., Stephan, S. \& Fanning, E. (1998). Replication factor C disengages from proliferating cell nuclear antigen (PCNA) upon sliding clamp formation, and PCNA itself tethers DNA polymerase delta to DNA. J. Biol. Chem. 273, 31992-31999.

18. Woese, C. R. \& Fox, G. E. (1977). Phylogenetic structure of the prokaryotic domain: the primary kingdoms. Proc. Natl. Acad. Sci. USA 74, 5088-5090.

19. Bult, C. J., White, O., Olsen, G. J., Zhou, L., Fleischmann, R. D., Sutton, G. G., Blake, J. A., FitzGerald, L. M., Clayton, R. A., Gocayne, J. D., et al. (1996). Complete genome sequence of the methanogenic Archaeon, Methanococcus jannaschii. Science 273, 1058-1073.

20. Smith, D. R., Doucette-Stamm, L. A., Deloughery, C., Lee, H., Dubois, J., Aldredge, T., Bashirzadeh, R., Blakely, D., Cook, R., Gilbert, K., et al. (1997). Complete genome sequence of Methanobacterium thermoautotrophicum deltaH: functional and comparative genomics. J. Bacteriol. 179, 7135-7155.

21. Klenk, H. P., Clayton, R. A., Tomb, J. F., White, O., Nelson, K. E., Ketchum, K. A., Dodson, R. J., Gwinn, M., Hickey, E. K., Peterson, J. D., et al. (1997). The complete 
genome sequence of the hyperthermophilic, sulphate-reducing archaeon Archaeoglobus fulgidus. Nature 390, 364-370.

22. Kawarabayasi, Y., Sawada, M., Horikawa, H., Haikawa, Y., Hino, Y., Yamamoto, S., Sekine, M., Baba, S., Kogusi, H., Hosoyama, A., et al. (1998). Complete sequence of the gene organization of the genome of a hyper-thermophilic archaebacterium, Pyrococcus horikoshii OT3. DNA Res. 5, 147-155.

23. Kawarabayasi, Y., Hino, Y., Horikawa, H., Yamazaki, S., Haikawa, Y., Jin-no, K., Takahashi, M., Sekine, M., Baba, S., Ankai, A., et al. (1999). Complete genome sequence of an aerobic hyper-thermophilic crenarchaeon, Aeropyrum pernix K1. DNA Res. 6, 83-101.

24. Charlebois, R. L., Singh, R. K., Chan-Weiher, C. C., Allard, G., Chow, C., Confalonieri, F., Curtis, B., Duguet, M., Erauso, G., Faguy, D., et al. (2000). Gene content and organization of a $281-\mathrm{kbp}$ contig grom the genome of the extremely thermophilic archaeon, Sulfolobus solfataricus P2. Genome 43, 116-136.

25. De Felice, M., Sensen, C. W., Charlebois, R. L., Rossi, M. \& Pisani, F. M. (1999). Two DNA polymerase sliding clamps from the thermophilic archaeon Sulfolobus solfataricus. J. Mol. Biol. 291, 47-57.

26. Edgell, D. R., Klenk, H. P. \& Doolittle, W. F. (1997). Gene duplications in evolution of archaeal family B DNA polymerases. J. Bacteriol. 179, 2632-2640.

27. Cann, I. K. O., Ishino, S., Nomura, N., Sako, Y. \& Ishino, Y. (1999). Two family B DNA polymerases from Aeropyrum pernix, an aerobic hyperthermophilic crenarchaeote. J. Bacteriol. 181, 5984-5992. 
28. Cann, I. K. O., Ishino, S., Hayashi, I., Komori, K., Toh, H., Morikawa, K. \& Ishino, Y. (1999). Functional interactions of a homolog of proliferating cell nuclear antigen with DNA polymerases in Archaea. J. Bacteriol. 181, 6591-6599.

29. Henneke, G., Raffin, J. P., Ferrari, E., Jónsson, Z. O., Dietrich, J. \& Hübscher, U. (2000). The PCNA from Thermococcus fumicolans functionally interacts with DNA polymerase delta. Biochem. Biophys. Res. Commun. 276, 600-606.

30. Cann, I. K. O., Komori, K., Toh, H., Kanai, S. \& Ishino, Y. (1998). A heterodimeric DNA polymerase: Evidence that members of Euryarchaeota possess a distinct DNA polymerase. Proc. Natl. Acad. Sci. USA 95, 14250-14255.

31. Cann, I. K. O. \& Ishino, Y. (1999). Archaeal DNA replication: Identifying the pieces to solve a puzzle. Genetics 152, 1249-1267.

32. Gueguen, Y., Rolland, J. L., Lecompte, O., Azam, P., Le Romancer, G., Flament, D., Raffin, J. P. \& Dietrich, J. (2001). Characterization of two DNA polymerases from the hyperthermophilic euryarchaeon Pyrococcus abyssi. Eur. J. Biochem. 268, 59615969.

33. Iwai, T., Kurosawa, N., Itoh, Y. H. \& Horiuchi, T. (2000). Phylogenetic analysis of archaeal PCNA homologues. Extremophiles 4, 357-364.

34. Pisani, F. M., De Felice, M., Carpentieri, F. \& Rossi, M. (2000). Biochemical characterization of a clamp-loader complex homologous to eukaryotic replication factor C from the hyperthermophilic archaeon Sulfolobus solfataricus. J. Mol. Biol. 301, 61-73. 
35. Cann, I. K. O., Ishino, S., Yuasa, M., Daiyasu, H., Toh, H. \& Ishino, Y. (2001). Biochemical analysis of Replication Factor $\mathrm{C}$ from the hyperthermophilic archaeon Pyrococcus furiosus. J. Bacteriol. 183, 2614-2623.

36. Kelman, Z. \& Hurwitz, J. (2000). A unique organization of the protein subunits of the DNA polymerase clamp loader in the archaeon Methanobacterium thermoautotrophicum $\Delta$ H. J. Biol. Chem. 275, 7327-7336.

37. Erauso, G., Reysenbach, A. L., Godfroy, A., Meunier, J. R., Crump, B., Partensky, F., Baross, J. A., Marteinsson, V., Barbier, G., Pace, N. R., et al. (1993). Pyrococcus abyssi sp. nov., a new hyperthermophilic archaeon isolated from a deep-sea hydrothermal vent. Arch. Microbiol. 160, 338-349.

38. Myllykallio, H., Lopez, P., Lopez Garcia, P., Heilig, R., Saurin, W., Zivanovic, Y., Philippe, H. \& Forterre, P. (2000). Bacterial mode of replication with eukaryotic-like machinery in a hyperthermophilic archaeon. Science 288, 2212-2215.

39. Bunz, F., Kobayashi, R. \& Stillman, B. (1993). cDNAs encoding the large subunit of human replication factor C. Proc. Natl. Acad. Sci. USA 90, 11014-11018.

40. Cullmann, G., Fien, K., Kobayashi, R. \& Stillman, B. (1995). Characterization of the five replication factor C genes of Saccharomyces cerevisiae. Mol. Cell. Biol. 15, 4661-4671.

41. Warbrick, E. (1998). PCNA binding through a conserved motif. Bioessays 20, 195199.

42. Podust, L. M., Podust, V. N., Sogo, J. M. \& Hübscher, U. (1995). Mammalian DNA polymerase auxiliary proteins: Analysis of replication factor C-catalyzed proliferating 
cell nuclear antigen loading onto circular double-stranded DNA. Mol. Cell. Biol. 15, 3072-3081.

43. Latham, G. J., Pietroni, P., Dong, F., Young, M. C. \& Von Hippel, P. H. (1996). Fluorescence monitoring of T4 polymerase holoenzyme accessory protein interactions during loading of the sliding clamp onto the template-primer junction. J. Mol. Biol. 264, 426-439.

44. Oliveira, L., Paiva, A. C. M., Sander, C. \& Vriend, G. (1994). A common step for signal transduction in G protein-coupled receptors. Trends Pharmacol. Sci. 15, 170172.

45. Thomm, M., Hausner, W. \& Hethke, C. (1994). Transcription factors and termination of transcription in Methanococcus. Syst. Appl. Microbiol. 16, 648-655.

46. Thomm, M. \& Wich, G. (1988). An archaebacterial promoter element for stable RNA genes with homology to the TATA box of higher eukaryotes. Nucleic Acids Res. 16, 151-163.

47. Pühler, G., Lottspeich, F. \& Zillig, W. (1989). Organization and nucleotide sequence of the genes encoding the large subunits A, B and C of the DNA-dependent RNA polymerase of the archaebacterium Sulfolobus acidocaldarius. Nucleic Acids Res. 17, 4517-4534.

48. Walker, J. E., Saraste, M., Runswick, M. J. \& Gay, N. J. (1982). Distantly related sequences in the $\alpha$ - and $\beta$-subunits of ATP synthase, myosin, kinases and other ATPrequiring enzymes and a common nucleotide binding fold. EMBO J. 1, 945-951. 
49. Uhlmann, F., Gibbs, E., Cai, J. S., O'Donnell, M. \& Hurwitz, J. (1997). Identification of regions within the four small subunits of human replication factor $\mathrm{C}$ required for complex formation and DNA replication. J. Biol. Chem. 272, 10065-10071.

50. Fotedar, R., Mossi, R., Fitzgerald, P., Rousselle, T., Maga, G., Brickner, H., Messier, H., Khastilba, S. \& Hübscher, U. (1996). A conserved domain of the large subunit of replication factor $\mathrm{C}$ binds PCNA and acts like a dominant negative inhibitor of DNA replication in mammalian cells. EMBO J. 15, 4423-4433.

51. Gomes, X. V., Gary, S. L. \& Burgers, P. M. J. (2000). Overproduction in Escherichia coli and characterization of yeast replication factor C lacking the ligase homology domain. J. Biol. Chem. 275, 14541-14549.

52. Perler, F. B. (1998). Splicing of inteins and hedgehog autoproteolysis : structure, function and evolution. Cell 92, 1-4.

53. Koonin, E. V. (1993). A common set of conserved motifs in a vast variety of putative nucleic acid-dependent ATPases including MCM proteins involved in the initiation of eukaryotic DNA replication. Nucleic Acids Res. 21, 2541-2547.

54. Oyama, T., Ishino, Y., Cann, I. K., Ishino, S. \& Morikawa, K. (2001). Atomic Structure of the Clamp Loader Small Subunit from Pyrococcus furiosus. Mol. Cell 8, $455-463$.

55. Ellison, V. \& Stillman, B. (2001). Opening of the Clamp. An Intimate View of an ATP-Driven Biological Machine. Cell 106, 655-60.

56. Podust, V. N., Tiwari, N., Ott, R. \& Fanning, E. (1998). Functional interactions among the subunits of replication factor $\mathrm{C}$ potentiate and modulate its ATPase activity. J. Biol. Chem. 273, 12935-12942. 
57. Green, C. M., Erdjument Bromage, H., Tempst, P. \& Lowndes, N. F. (2000). A novel Rad24 checkpoint protein complex closely related to replication factor C. Curr. Biol. 10, 39-42.

58. Venclovas, C. \& Thelen, M. P. (2000). Structure-based predictions of Rad1, Rad9, Hus1 and Rad17 participation in sliding clamp and clamp-loading complexes. Nucleic Acids Res. 28, 2481-2493.

59. Ishino, Y., Tsurimoto, T., Ishino, S. \& Cann, I. K. (2001). Functional interactions of an archaeal sliding clamp with mammalian clamp loader and DNA polymerase $\delta$. Genes Cells 6, 699-706.

60. Mayanagi, K., Miyata, T., Oyama, T., Ishino, Y. \& Morikawa, K. (2001). ThreeDimensional Electron Microscopy of the Clamp Loader Small Subunit from Pyrococcus furiosus. J. Struct. Biol. 134, 35-45.

61. Motz, M., Kober, I., Girardot, C., Loeser, E., Bauer, U., Albers, M., Moeckel, G., Minch, E., Voss, H., Kilger, C., et al. (2002). Elucidation of an archaeal replication protein network to generate enhanced PCR enzymes. J. Biol. Chem. 277, 1617916188.

62. Thompson, J. D., Higgins, D. G. \& Gibson, T. J. (1994). CLUSTAL W : improving the sensitivity of progressive multiple sequence alignment through sequence weighting, position-specific gap penalties and weight matrix choice. Nucleic Acids Res. 22, 4673-4680.

63. Ho, S. N., Pullen, J. K., Horton, R. M., Hunt, H. D. \& Pease, L. R. (1990). DNA and protein engineering using the polymerase chain reaction: splicing by overlap extension. DNA Prot. Eng. tech. 2, 50-55. 
64. Bradford, M. M. (1976). A rapid and sensitive method for the quantitation of microgram quantities of protein using the principle of protein-dye binding. Anal. Biochem. 72, 248-254.

65. Yoder, B. L. \& Burgers, P. M. (1991). saccharomyces cerevisiae Replication Factor C. I. Purification and characterization of its ATPase activity. J. Biol. Chem. 266, 22698-22697.

66. Ellison, V. \& Stillman, B. (1998). Reconstitution of recombinant human replication factor C (RFC) and identification of an RFC subcomplex possessing DNA-dependent ATPase activity. J. Biol. Chem. 273, 5979-5987.

67. Cai, J., Uhlmann, F., Gibbs, E., Flores Rozas, H., Lee, C. G., Phillips, B., Finkelstein, J., Yao, N., O'Donnell, M. \& Hurwitz, J. (1996). Reconstitution of human replication factor C from its five subunits in baculovirus-infected insect cells. Proc. Natl. Acad. Sci. USA 93, 12896-12901.

68. Lee, S. H., Kwong, A. D., Pan, Z. Q. \& Hurwitz, J. (1991). Studies on the activator 1 protein complex, an accessory factor for proliferating cell nuclear antigen-dependent DNA polymerase $\delta$. J. Biol. Chem. 266, 594-602. 
Table 1 : Summary of the effects of DNA and PCNA on the ATPase activity of eukaryotic and archaeal RFC complexes.

\begin{tabular}{|l|c|c|c|c|l|}
\hline \multirow{2}{*}{ Human } & \multirow{2}{*}{ Effect of DNA } & \multicolumn{2}{|c|}{ Effect of PCNA } & \multirow{2}{*}{ SSB protein } & \\
\cline { 3 - 4 } & & - DNA & + DNA & & \\
\hline S. cerevisiae & highly dependent & no effect & high effect & not required & $12,66,67,68$ \\
\hline M. thermoautotrophicum & highly dependent & no effect & high effect & not required & 6,65 \\
\hline S. solfataricus & highly dependent & no effect & high effect & required & 36 \\
\hline P. furiosus & moderately dependent & inhibition & high effect & not tested & 35 \\
\hline P. abyssi & not dependent & no effect & high effect & not tested & this study \\
\hline
\end{tabular}

(*): reverses the inhibition by the RPA protein. 


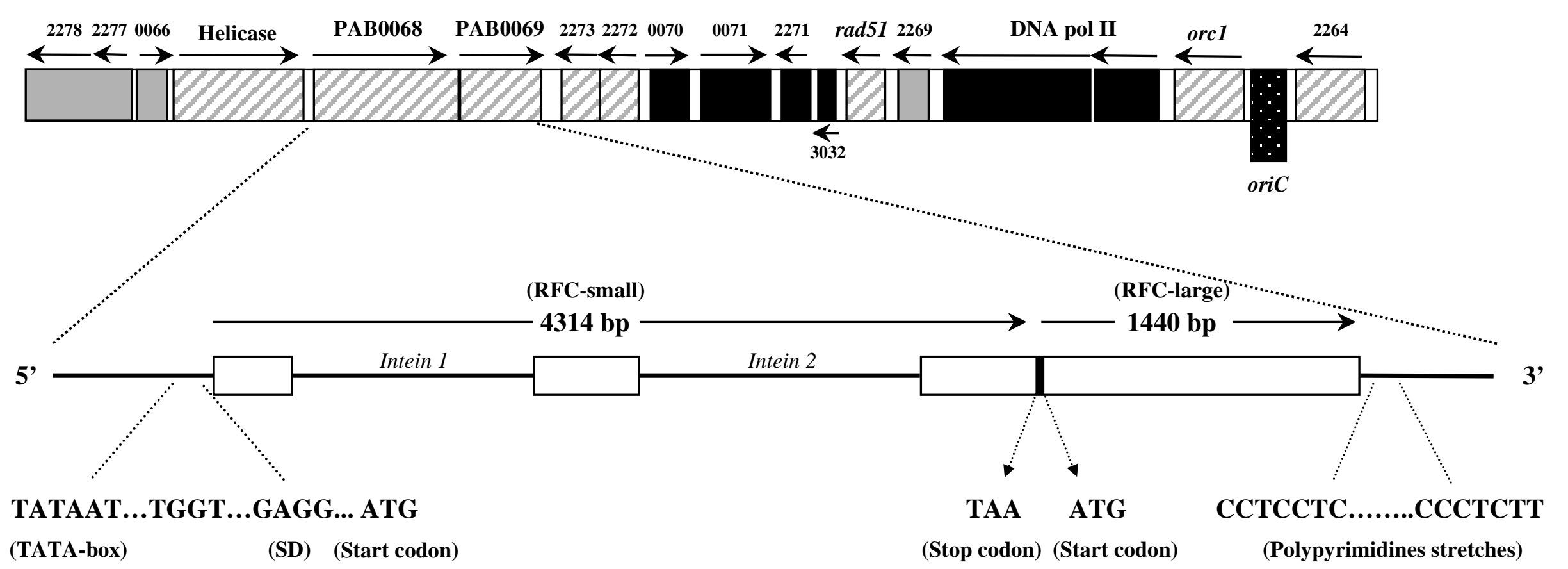


(a)

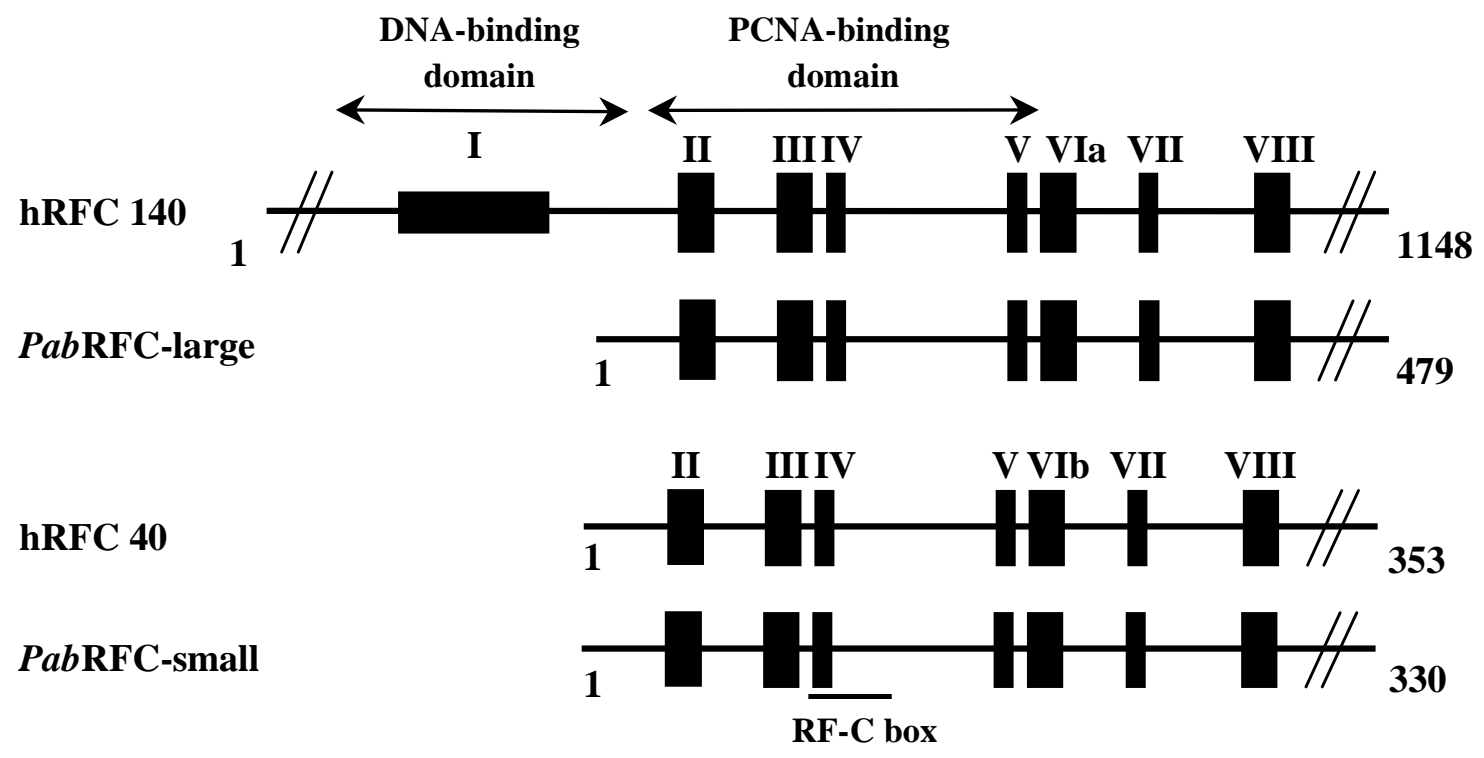

(c)
Homo sapiens

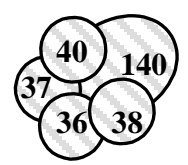

Sulfolobus solfataricus

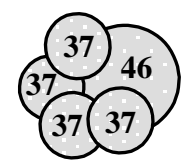

Methanobacterium thermoautotrophicum

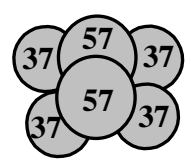

Pyrococcus furiosus

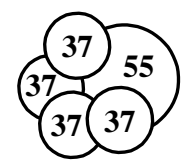

VIII (b)
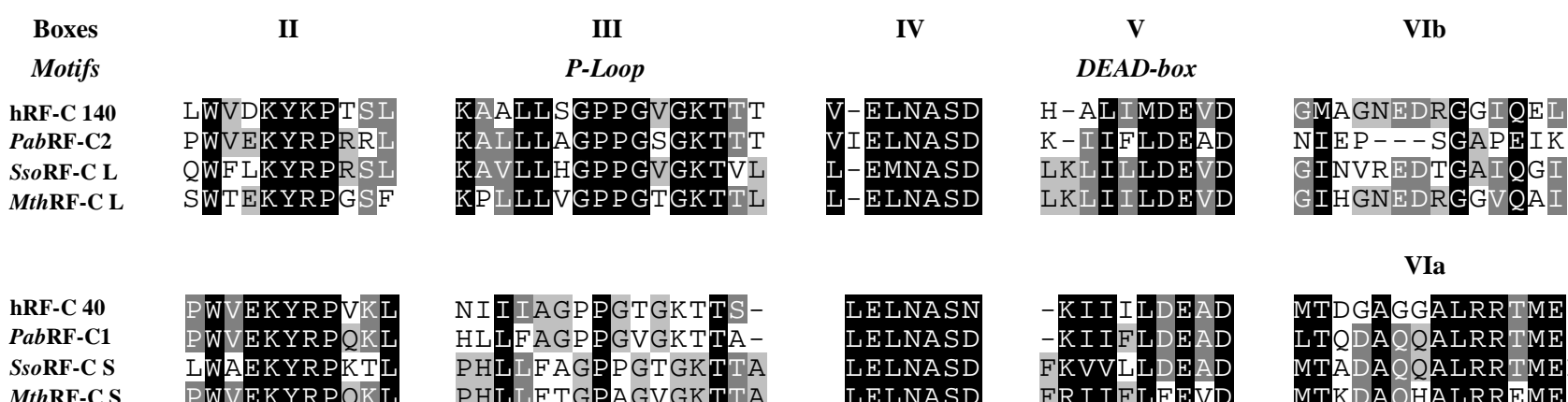

VII

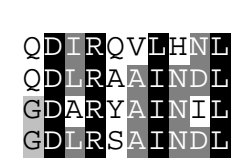

VIa
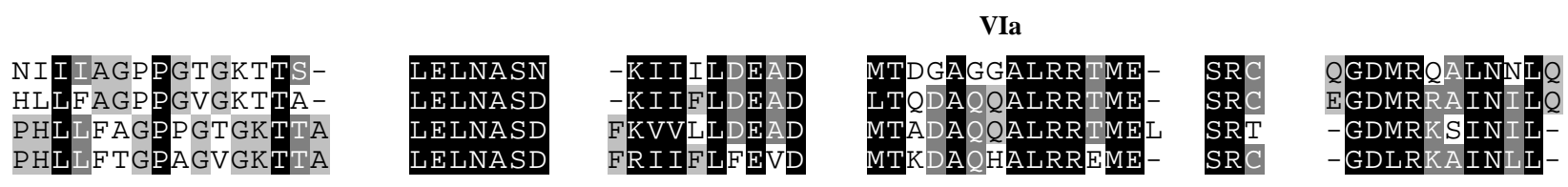


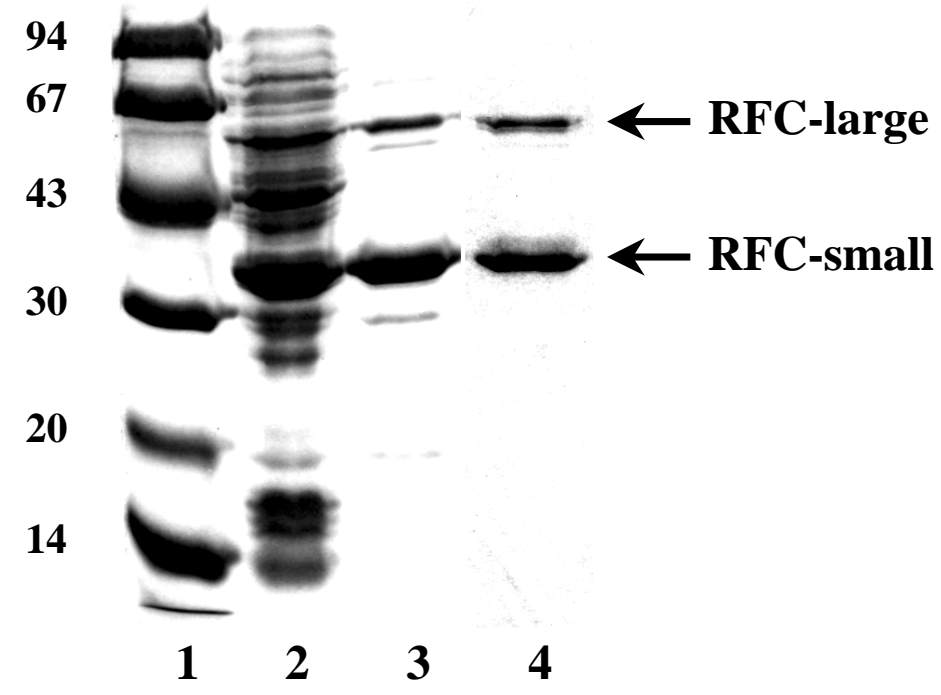




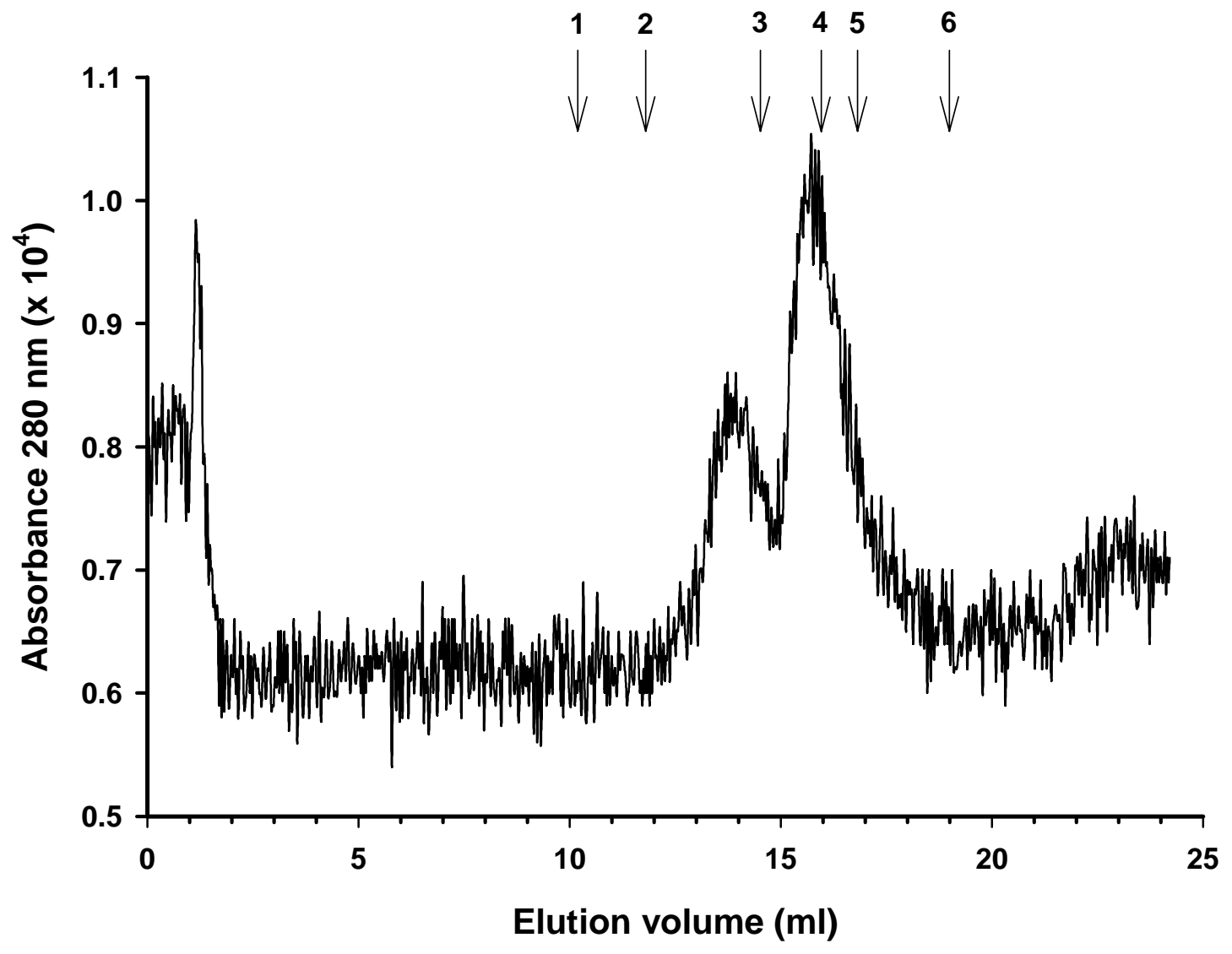




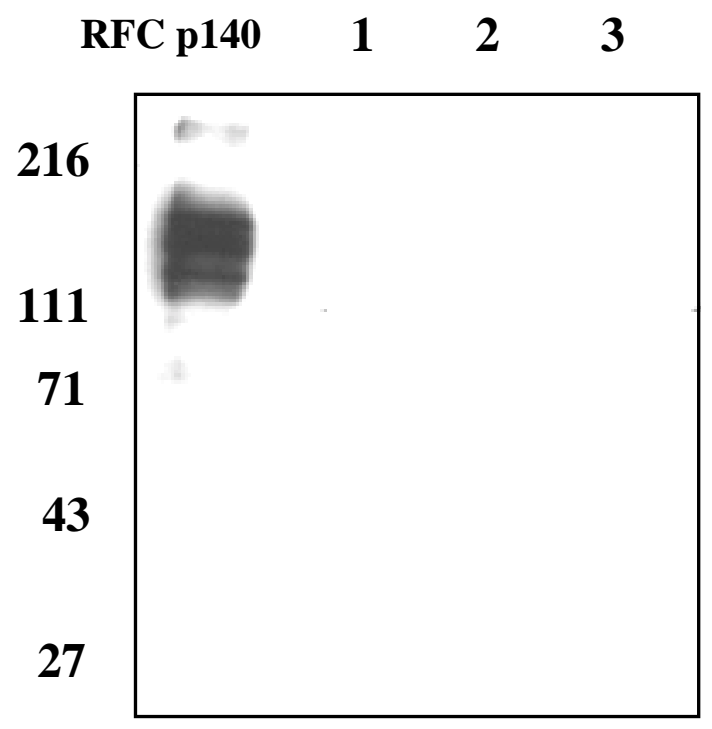

DNA-binding domain monoclonal anti-human RFC 140 antibody

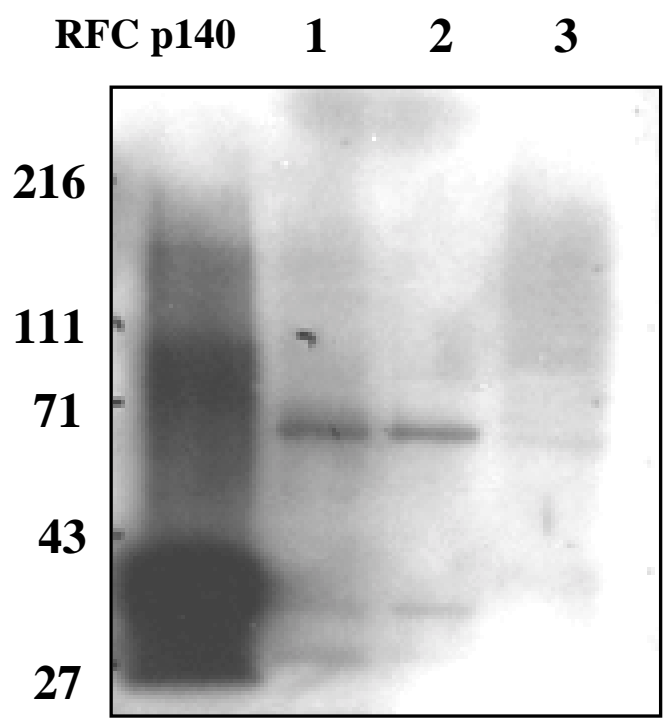

PCNA-binding domain polyclonal anti-human RFC 140 antibody 
(a)

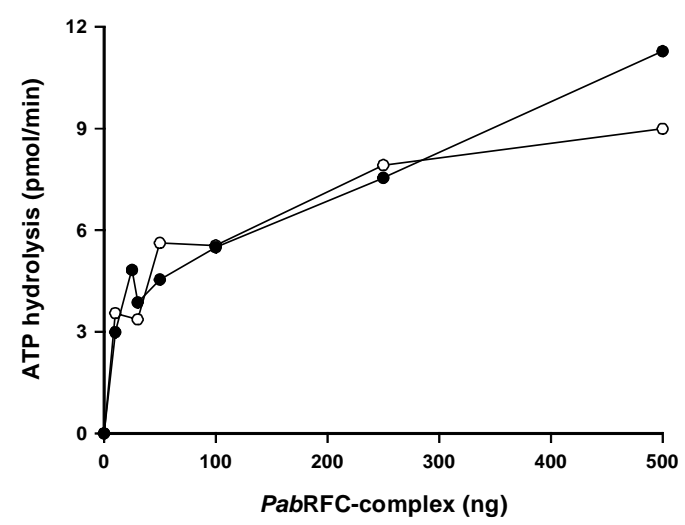

(c)

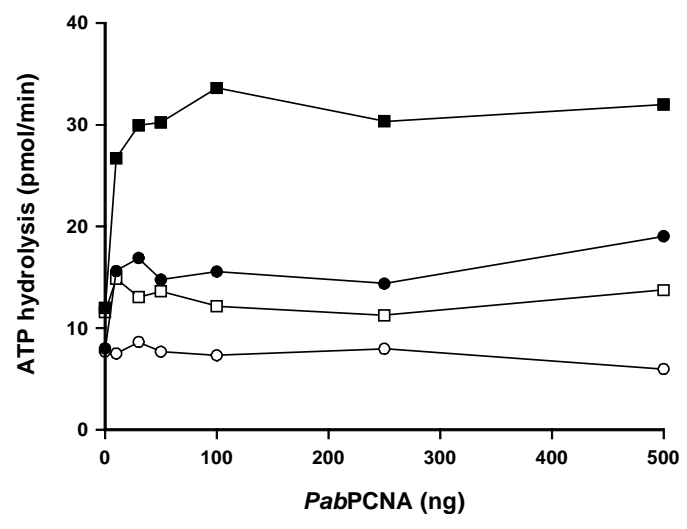

(b)

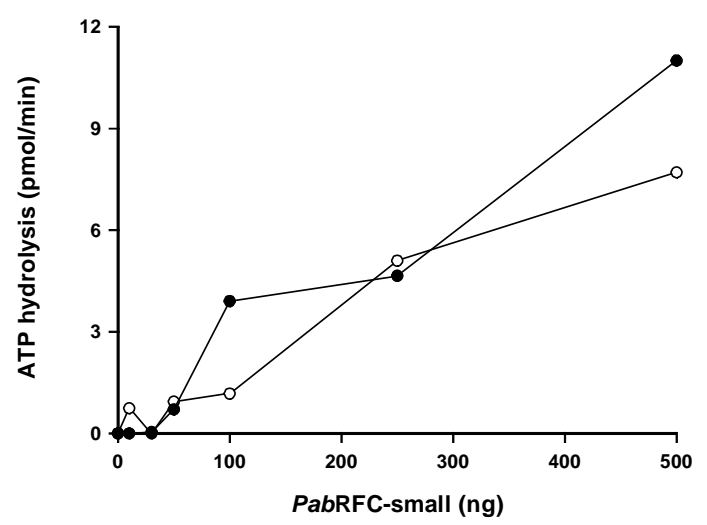

(d)

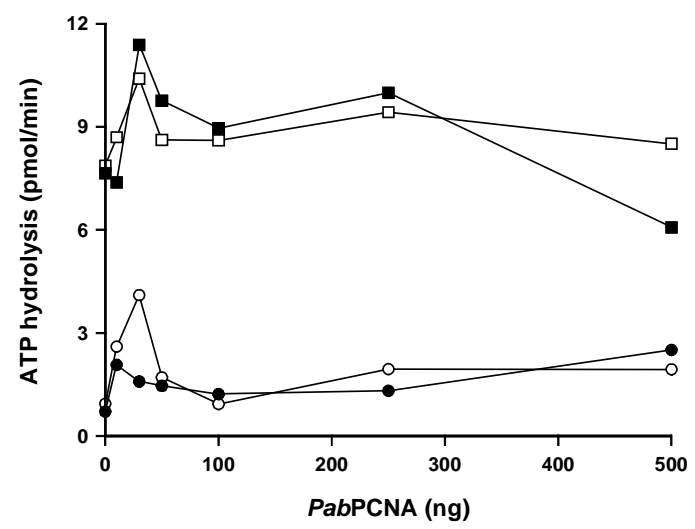


(a)

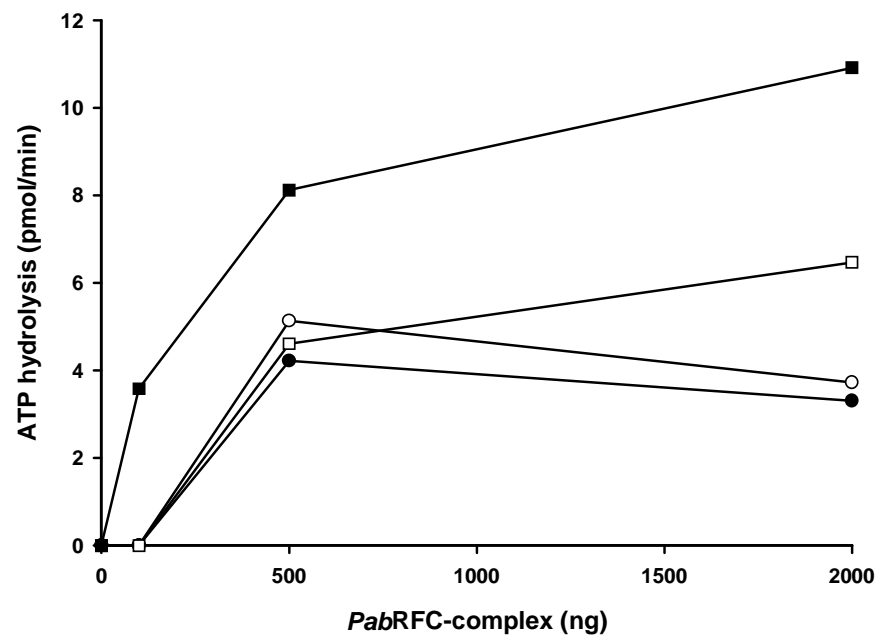

(b)

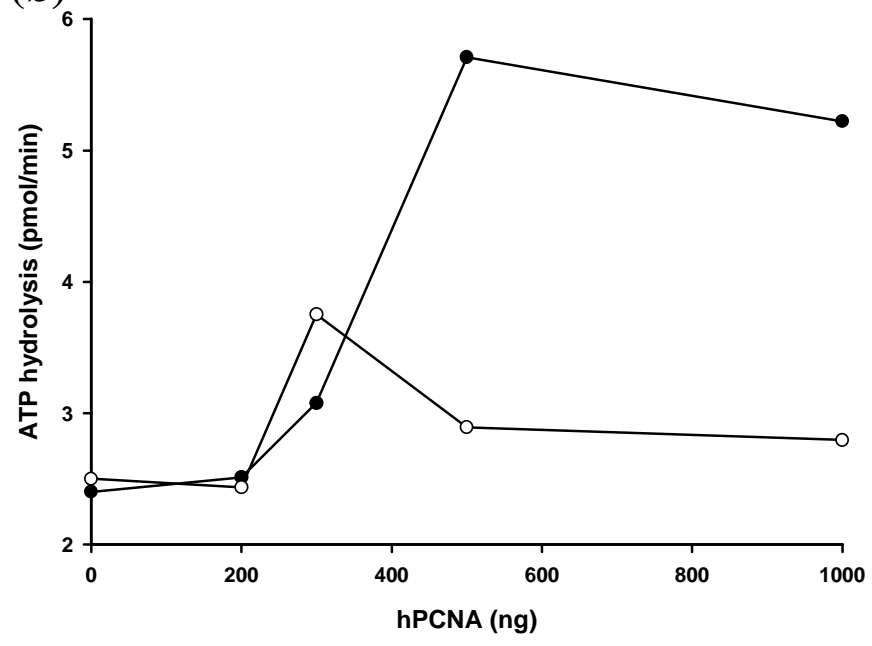




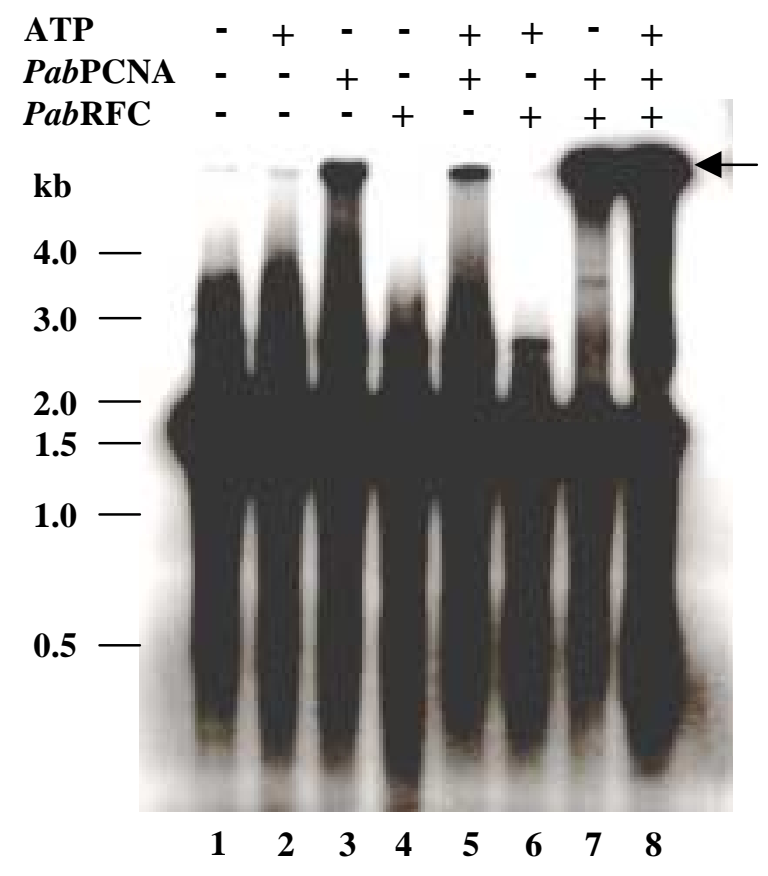




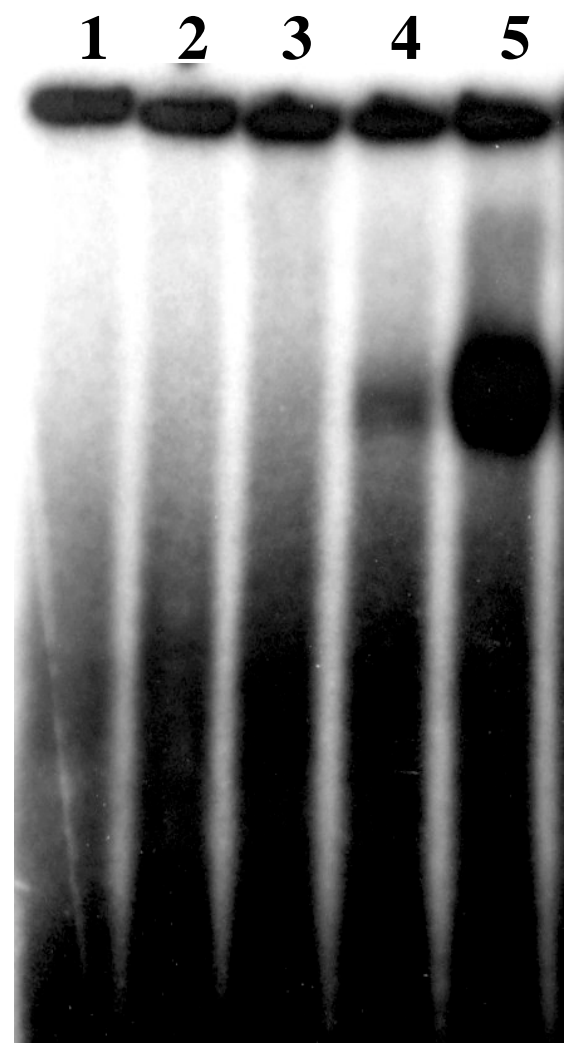

